UDK: $347.51: 347.513$

Pregledni znanstveni rad

Primljen: 29. travnja 2018.

Prihvaćen: 7. lipnja 2018.

Mr. sc. Jerko LIVAJA,

Ministarstvo unutarnjih poslova Herecegovačko-neretvanske županije

jlivaja@gmail.com

\title{
OGRANIČENJE I ISKLJUČENJE ODGOVORNOSTI ZA ŠTETU IZAZVANU NEISPRAVNIM PROIZVODOM - EUROPSKI, AMERIČKI I DOMAĆI MODEL ODGOVORNOSTI ZA ŠTETU
}

Sažetak: Rad se bavi istraživanjem pravila o isključenju i ograničenju odgovornosti proizvođača neispravnog proizvoda u dva vodeća modela izvanugovorne odgovornosti za štetu od neispravnog proizvoda, američkog modela iz Restatementa i europskog modela iz Direktive Vijeća 85/374/EEZ od 25. srpnja 1985. o približavanju zakona i drugih propisa država članica $u$ vezi s odgovornošću za neispravne proizvode, te institutom izvanugovorne odgovornosti proizvođača stvari s nedostatkom koji je zadržan u pozitivnom zakonodavstvu država nastalih raspadom Socijalističke Federativne Republike Jugoslavije. U istom će se pokušati ukazati na prednosti i nedostatke američkog $i$ europskog modela izvanugovorne odgovornosti za štetu od neispravnog proizvoda, kao i sustava izvanugovorne odgovornosti proizvođača stvari s nedostatkom iz čl. 179. Zakona o obveznim odnosima Bosne i Hercegovine, glede pravila o ograničenju, umanjenju $i$ isključenju odgovornosti proizvođača neispravnog proizvoda. Također, rad se bavi i problemima implementacije Direktive Vijeća 85/374/EEZ od 25. srpnja 1985. godine u državama članicama Europske unije, glede pravila o ograničenju i isključenju odgovornosti proizvođača neispravnog proizvoda, s posebnim naglaskom na implementaciju ove Direktive u domaće zakonodavstvo i zakonodavstvo država u okruženju.

Ključne riječi: neispravan proizvod, izvanugovorna odgovornost za štetu, ograničenje odgovornosti za štetu, umanjenje odgovornosti za štetu, isključenje odgovornosti za štetu, solidarna odgovornost, harmonizacija prava, horizontalni učinak direktiva. 


\section{Uvodne napomene}

Pravila o izvanugovornoj odgovornosti za štetu od neispravnog proizvoda danas su uglavnom samostalna pravna cjelina unutar pravila odgovornosti za štetu. Pod tim se ne podrazumijeva da su ona u potpunosti izolirana pravna cjelina, u smislu potpune neovisnosti od općih i posebnih pravila odgovornosti za štetu. Bez obzira koliko pravila o izvanugovornoj odgovornosti za štetu izazvanu neispravnim proizvodom u sadržajnom smislu egzistiraju kao samostalni dio odštetnog prava, pojedini opći instituti odštetnog prava uključujući i temeljna pravna načela njihov su sastavni dio. To je posebno vidljivo u domaćim pravilima izvanugovorne odgovornosti proizvođača stvari s nedostatkom. Naime, odredba čl. 179. Zakona o obveznim odnosima Bosne i Hercegovine ${ }^{1}$ s kojom je normirana odgovornost proizvođača stvari s nedostatkom, u sadržajnom smislu toliko je siromašna da je njome tek toliko propisana odgovornost proizvođača stvari s nedostatkom na načelu objektivne odgovornosti, s tim da je njegova odgovornost za opasna svojstva stvari ublažena načelom subjektivne odgovornosti, dok sve ostale institute, uključujući i ograničenje i isključenje odgovornosti štetnika, uređuju opća i posebna pravila odštetne odgovornosti.

S druge strane, pravila o odgovornosti proizvođača neispravnog proizvoda iz europskog modela koja su uređena Direktivom Vijeća 85/374/EEZ od 25. srpnja 1985. o približavanju zakona i drugih propisa država članica u vezi s odgovornošću za neispravne proizvode (dalje u tekstu: Direktiva 85/374/EEZ), ${ }^{2}$ te Direktivom 1999/34/EZ Europskog parlamenta i Vijeća od 10. svibnja 1999. o izmjeni Direktive 85/374/EEZ o usklađivanju zakona i drugih propisa država članica u vezi s odgovornošću za neispravne proizvode, ${ }^{3}$ predstavljaju u sadržajnom smislu potpuno zaokruženu cjelinu. ${ }^{4}$ Europski model iz Direktive 85/374/EEZ ovu vrstu izvanugovorne odgovornosti za štetu normira u potpunosti, ${ }^{5}$ uključujući i pravila o ograničenju

\footnotetext{
${ }^{1}$ Zakon o obveznim odnosima Bosne i Hercegovine, Službeni list SFRJ, br. 29/78, 39/85, 45/89 i 57/89, Službeni list RBiH, br. 2/92, 13/93 i 13/94, Službene novine FBiH, br. 29/03 i 42/11, Službeni glasnik RS, br. 17/93, 3/96, 39/03 i 74/04.

${ }^{2}$ Direktiva Vijeća 85/374/EEZ od 25. srpnja 1985. o približavanju zakona i drugih propisa država članica u vezi s odgovornošću za neispravne proizvode, Službeni list EU L 210, 07.08.1985., str. 29.-33.

${ }^{3}$ Direktiva 1999/34/EZ Europskog parlamenta i Vijeća od 10. svibnja 1999. o izmjeni Direktive 85/374/EEZ o usklađivanju zakona i drugih propisa država članica u vezi s odgovornošću za neispravne proizvode, Službeni list EU L 141, 04.06.1999., str. 20.-21.

${ }^{4}$ U nastavku će se pojam Direktiva 85/374/EEZ koristiti kao kolokvijalni naziv za obje direktive, tj. za Direktivu iz 1985. i Direktivu iz 1999. godine.

${ }^{5}$ Direktiva 85/374/EEZ u potpunosti regulira pravila odgovornosti za neispravan proizvod na specifičan način, ne dopuštajući nacionalnim pravnim sustavima država članica da u postupku njene implementacije odstupe od pravila koja ona propisuje. S druge strane, Direktiva izričito određuje na koje se segmente odgovornosti za štetu od neispravnog proizvoda neće primjenjivati njena pravila, prepuštajući slobodu njihovog pravnog reguliranja državama članicama.
} 
i isključenju odgovornosti proizvođača neispravnog proizvoda, s tim da su pravila o isključenju odgovornosti uređena sustavom numerus clausus.

Američki sustav izvanugovorne odgovornosti za štetu proizvođača neispravnog proizvoda počiva na običajnom pravu (common law) baziranom na sustavu presedana. Zbog toga posebnu ulogu ima Američki pravni institut - American Law Institute (dalje u tekstu: ALI), koji sustavom Restatementa ${ }^{6}$ doprinosi ujednačavanju prava na cijelom području američke federacije. Iako američki sudovi nisu vezani pravilima iz Restatementa u smislu njihove obveznosti, pravila iz Restatementa, budući da objedinjuju pravnu teoriju i američku sudsku praksu, uključujući i praksu Vrhovnog suda Sjedinjenih Američkih Država koji ima zadnju riječ u tumačenju prava za čitavo područje SAD-a, djeluju snagom općeprihvaćenih pravnih stajališta. Slično kao i u domaćem modelu odgovornosti proizvođača stvari s nedostatkom, pravila o ograničenju i isključenju odgovornosti štetnika (proizvođača i drugih osoba s njim izjednačenih u odgovornosti) nisu dijelom posebnih pravila o odgovornosti proizvođača neispravnog proizvoda iz Restatementa, nego su dio općih i posebnih pravila odštetnog prava.

Domaći model izvanugovorne odgovornosti proizvođača stvari s nedostatkom temelji se samo na jednom članku. ${ }^{7}$ Istim je propisana stroga objektivna odgovornost proizvođača stvari s nedostatkom, na način da je ista ublažena subjektivnom odgovornošću proizvođača za opasna svojstva stvari. Budući da su ovim člankom samo utvrđena načela odgovornosti proizvođača za štetu prouzročenu od stvari s nedostatkom, pravila o ograničenju i isključenju odgovornosti proizvođača dio su općih i posebnih pravila odgovornosti za štetu.

\footnotetext{
${ }^{6}$ Restatementi nemaju obveznu snagu i predstavljaju, ustvari, specifičan oblik pravne literature. Često su izloženi kritici zbog toga što umjesto da prikažu pravo kakvo ono stvarno jeste, prikazuju kakvo bi ono trebalo biti. Američki pravni institut (ALI), pod čijim okriljem se pripremaju, osnovan je s ciljem da u sažetom i sistematičnom obliku predstavi važeće opće običajno pravo SAD-a ("general common law") u deset pravnih oblasti: zastupanje, sukob zakona, ugovori, pravo inozemnih odnosa, presude, imovina, neosnovano bogaćenje, sredstva osiguranja, delikti i trustovi. To se čini u formi pravila (black-letter rules) koja su popraćena komentarima i navodima sudskih odluka u kojima je citirano pravilo primijenjeno. STANIVUKOVIĆ, M., Instrumenti unifikacije i harmonizacije prava i njihov odnos prema kolizionim normama, s posebnim osvrtom na Načela evropskog ugovornog prava, Zbornik referata sa savetovanja „Načela evropskog ugovornog prava i jugoslovensko pravo“, Kragujevac, 2001., str. 84.

${ }^{7}$ Ova vrsta odgovornosti za štetu u domaćem zakonodavstvu počiva na članku 179. Zakona o obveznim odnosima, gdje je propisano sljedeće:

(1) Tko stavi u promet neku stvar koju je proizveo, a koja zbog nekog nedostatka za koji on nije znao predstavlja opasnost štete za osobe ili stvari, odgovara za štetu koja bi nastala zbog tog nedostatka.

(2) Proizvođač odgovara i za opasna svojstva stvari ako nije poduzeo sve što je potrebno da štetu, koju je mogao predvidjeti, spriječi upozorenjem, sigurnom ambalažom ili drugom odgovarajućom mjerom.
} 


\section{Općenito o ograničenju i isključenju odgovornosti za štetu izazvanu neispravnim proizvodom - sličnosti i razlike}

Pravna pravila izvanugovorne odgovornosti za štetu izazvanu neispravnim proizvodom, kojima su obuhvaćeni slučajevi u kojima štetnik ne odgovara za prouzročenu štetu, načelno ćemo podijeliti u dvije grupe - na pravila o ograničenju i pravila o isključenju odgovornosti za štetu. Dok pravilima o ograničenju odgovornosti zakonodavac istu izričito ograničava $u$ kvalitativnom i kvantitativnom smislu, pravilima o isključenju odgovornosti zakonodavac propisuje mogućnost potpunog ili djelomičnog isključenja odgovornosti proizvođača ne dovodeći u pitanje vrstu ili visinu iznosa štete. Dok se u slučajevima potpunog isključenja odgovornosti štetnik u potpunosti oslobađa odgovornosti, u slučajevima podijeljene odgovornosti njegova se odgovornost umanjuje na preostali dio štete izvan doprinosa tih osoba u nastanku štete. ${ }^{8}$ Kad su u pitanju slučajevi djelomičnog isključenja odgovornosti, radi se ustvari o različitim inačicama podijeljene odgovornosti između štetnika, oštećenika i treće osobe. Iako se, primjerice, i kod podijeljene odgovornosti odgovornost štetnika ograničava na preostali dio iznosa naknade štete izvan doprinosa treće osobe ili oštećenika, odnosno osobe za koju oni odgovaraju, time se općenito ne dira u vrstu ili visinu iznosa nastale štete.

U materijalnom i procesnom smislu kod ograničenja odgovornosti za štetu, odgovornost štetnika, odnosno odgovorne osobe ograničava se po sili zakona u kvalitativnom ili kvantitativnom smislu, ${ }^{9,} 10$ a kod isključenja odgovornosti štetnik se isticanjem odgovarajućeg

\footnotetext{
${ }^{8}$ Šteta koju netko pretrpi može biti posljedica ne samo tuđeg, nego i vlastitog ponašanja, u slučaju kada oštećeni svojim postupcima omogući drugome da mu štetu prouzrokuje ili doprinese da bude veća nego bi inače bila, shodno članu 192. Zakona o obligacionim odnosima. Krivica oštećenog, u smislu građanskopravne odgovornosti, može biti razlog za isključenje ili umanjenje odgovornosti počinioca štete, u zavisnosti od udela jedne i druge strane u prouzrokovanju štete. Iz presude Apelacionog suda u Nišu, Gž, 1812/2011 od 16.09.2011., dostupno na: $<$ http://www.iio.org.rs/Files/view/59> (7.1.2018.).

9 Štetniku, odnosno odgovornoj osobi bez obzira što je utvrđeno da je isti prouzročio štetu (u normalnim okolnostima bio bi odgovoran) zakonodavac iz određenih pravno-političkih razloga ograničava odgovornost $u$ kvalitativnom smislu po vrsti štete ili kvantitativnom smislu do određenog iznosa. Kvalitativno, na način, da ograničava odgovornost samo na imovinsku (materijalnu) štetu isključujući neimovinsku štetu ili obrnuto, kao i slučajevima kad istu ograničava na pravno određenu stvar, te kvantitativno, ograničavajući štetu samo do određenog iznosa propisivanjem gornje ili donje granice visine iznosa štete za koju se odgovara.

${ }^{10}$ Tako, primjerice, europski zakonodavac u čl. 9. Direktive 85/374/EEZ kvantitativno i kvalitativno ograničava odgovornost proizvođača neispravnog proizvoda na sljedeći način:

Za potrebe članka 1. 'šteta' znači:

a) šteta nastala smrću ili tjelesnim ozljedama;

b) šteta na bilo kojem predmetu, ili uništenje bilo kojeg predmeta ili imovine osim samog neispravnog proizvoda, s donjim pragom od $500 \mathrm{Ecu}$, pod uvjetom da je dio vlasništva:

i) takve vrste koja je obično namijenjena za privatnu uporabu ili potrošnju; i

ii) da ga je oštećena osoba uglavnom upotrebljavala za svoju vlastitu uporabu ili potrošnju.

Ovaj članak ne dovodi u pitanje nacionalne odredbe koje se odnose na nematerijalnu štetu.
} 
prigovora sam ekskulpira od odgovornosti u potpunosti ili djelomično ako su ispunjene odgovarajuće zakonske pretpostavke. Polazeći od osnovnih pretpostavki za ograničenje odgovornosti za štetu, dolazimo do spoznaje da za njenu primjenu nisu potrebne dodatne pretpostavke, za razliku od normi o isključenju i djelomičnom isključenju odgovornosti koje su uvijek određene i dodatnim pretpostavkama. Za razliku od normi koje se odnose na ograničenje odgovornosti i koje su u nomotehničkom smislu uvijek zakonski kvantitativno i kvalitativno određene (npr. ograničenje najnižeg, odnosno najvišeg iznosa štete za koju se odgovara, ili ograničenje odgovornosti na materijalnu, odnosno nematerijalnu štetu), norme o isključenju, odnosno djelomičnom isključenju odgovornosti za štetu određene su i dodatnim pretpostavkama (primjerice viša sila, slučaj, doprinos treće osobe, krivnja štetnika, krivnja oštećenika i sl.).

\section{Europski model - Direktiva 85/374/EEZ}

Današnji europski model izvanugovorne odgovornosti za štetu izazvanu neispravnim proizvodom rezultat je implementacije Direktive 85/374/EEZ u nacionalna zakonodavstva država članica Europske unije. ${ }^{11}$ Direktiva ${ }^{12}$ kao oblik zakonodavnog djelovanja Europske unije pripada onoj vrsti europskog sekundarnog zakonodavstva koje se ne može primijeniti izravno u državama članicama. Iako je Osnivačkim ugovorima ${ }^{13}$ određeno da isključivo uredba $^{14}$ i odluka ${ }^{15}$ ima izravno djelovanje u svim državama članicama Unije, s tom razlikom što se odluke uvijek odnose na konkretne slučajeve, dok su uredbe apstraktnog karaktera, aktualna sudska praksa Sud Europske unije (Court of Justice of the European Union), upravo

\footnotetext{
${ }^{11}$ Samo su tri države članice nakon slanja obavijesti 30. srpnja 1985. godine implementirale Direktivu u predviđenom roku od tri godine od dana slanja obavijesti, i to: Ujedinjeno Kraljevstvo 1. ožujka 1988., Italija 29. lipnja 1988. i Grčka 30. srpnja 1988. godine. Izuzimajući europske države koje su kasnije ulazile u Europsku uniju, Francuska je zadnja država članica koja je implementirala ovu Direktivu. Ona je to učinila tek 21. svibnja 1998. godine. Isto se ne odnosi na države koje su kasnije postale članice Unije.

${ }^{12}$ Direktiva je pravno-obvezujući akt upućen državama članicama, pri čemu su one obvezane ciljem i sadržajem direktive, ali ne i načinom njihovog ostvarivanja u nacionalnom pravnom poretku. MISITA, N., Osnovi prava Evropske unije, Pravni fakultet Univerziteta u Sarajevu, Sarajevo, 2008., str. 500.

${ }^{13}$ Pojmom Osnivački ugovori obuhvaćeni su ugovori s kojima su osnovane Europske zajednice i Europska unija. Danas formalnopravno postoji samo Lisabonski ugovor kojim se mijenjaju i dopunjuju Ugovor o Europskoj uniji i Ugovor o osnivanju Europske zajednice. Ugovor je potpisan u Lisabonu 13. prosinca 2007. godine. On je predvidio pristupanje Republike Hrvatske Europskoj uniji, što je i učinjeno potpisivanjem pristupnog ugovora u Briselu 9.12.2011. godine. Od 1.7.2013. godine Republika Hrvatska je punopravna članica Unije.

${ }^{14}$ Uredba je propis koji karakterizira općenitost, apstraktnost, obveznost i neposredna primjenjivost u državama članicama. MISITA, N., op. cit., str. 495.

${ }^{15}$ Odluka je pravni akt koji obvezuje u cijelosti one kojima je upućena, odnosno one koji su u njoj imenovani. MISITA, N., op. cit., str. 505.
} 
u svezi s primjenom Direktive 85/374/EEZ ukazuje na suprotno budući da je ovaj sud u slučaju Commision v. $U K^{16}$ prihvatio izravni horizontalni učinak ove Direktive. ${ }^{17}$ Naime, iako je Direktiva 85/374/EEZ, kao i druge direktive, takva vrsta zakonodavnog akta koji se oživotvoruje tek kroz zakonodavnu djelatnost država članica, na način da se njezine odredbe na odgovarajući način implementiraju u nacionalno zakonodavstvo članica Unije, svojom odlukom u gore navedenom predmetu Sud Europske unije stvorio je svojevrsni presedan. Prihvaćajući da je ispravno implementirano ono što u stvarnosti (formalno-pravno) nije, s jednom „nadom“ da će engleski sudovi domaći zakon tumačiti u skladu s Direktivom, ${ }^{18,19}$ te samim tim donositi odluke contra legem, tj. da će se njihove odluke temeljiti na odredbi čl. 7(e) Direktive, a ne na odredbi čl. 4(1) nacionalnog Zakona o zaštiti potrošača - Consumer Protection Act (dalje u tekstu: CPA), ${ }^{20}$ Sud Europske unije prihvaća izravni horizontalni učinak Direktive 85/374/EEZ. S tim u vezi postavlja se i pitanje zakonitosti odluka sudova Ujedinjenog Kraljevstva, odnosno postavlja se pitanje širine diskrecijskih ovlasti engleskih sudova $\mathrm{u}$ tumačenju domaćeg prava praeter ili contra legem budući da je u čl. 4(1) CPA ${ }^{21}$ izričito i nedvosmisleno određeno da se stanje znanosti i tehničkog znanja odnosi na određeno proizvodno područje, tj. na skrivljeno ponašanje proizvođača iz određene struke - proizvodnog područja u izbjegavanju štetnih posljedica primjenom takvog znanstveno-tehničkog znanja.

Odluka Suda Europske unije je drugačija i ne treba je dovoditi u kontekst ranijih i kasnijih presuda, u kojima je Sud Europske unije prihvaćao da su nacionalni sudovi dužni tumačiti domaće pravo u skladu s ciljevima koji se njima trebaju postići, odnosno postižu, pa čak i u slučajevima kad europsko pravo nema obligatorni karakter, kao što je to slučaj sa preporukama. $^{22,23}$ Slučaj C-300/95 odnosio se isključivo na ispravnost implementacije

\footnotetext{
${ }^{16}$ Presuda Commission of the European Communities v. United Kingdom of Great Britain and Northern Ireland, C-300/95, EU:C:1997:255.

${ }^{17}$ LIVAJA, J., Obrana razvojnim rizikom u europskom odštetnom pravu i pravu Bosne i Hercegovine, magistarski znanstveni rad, Pravni fakultet Sveučilišta u Mostaru, 2013., str. 125.-127.

${ }^{18} \mathrm{Ibid}$, str. 126.

${ }^{19}$ Obrazlažući presudu od 29. svibnja 1997. godine (Case C-300/95) kojom je presuđeno da je Ujedinjeno Kraljevstvo ispravno implementiralo Direktivu 85/374/EEZ, Sud Europske unije u stavku 38. presude ističe kako ne postoji ništa što bi upućivalo da sudovi Ujedinjenog kraljevstva neće tumačiti domaće zakonodavstvo u svjetlu teksta i cilja Direktive, a sve kako bi se postigao učinak u skladu sa člankom 189 (3) Ugovora. Nadalje, kao potvrdu ispravnosti svog stava Sud dodaje kako je Zakon kojim je implementirana Direktiva 85/374/EEZ takvu obvezu izričito nametnuo nacionalnim sudovima Ujedinjenog Kraljevstva.

${ }^{20}$ Consumer Protection Act 1987 (1987 Chapter 43).

${ }^{21}$ Consumer Protection Act 1987 (Chapter 43, Part 1, § 4 - Defences), propisuje sljedeće:

That the state of scientific and technical knowledge at the relevant time was not such that a producer of products of the same description as the product in question might be expected to have discovered the defect if it had existed in his products while they were under his control.

${ }^{22}$ Presuda Salvatore Grimaldi v. Fonds des maladies professionnelles, C-322/88, EU:C:1989:646.

${ }^{23}$ Presuda Deutsche Shell AG v. Hauptzollamt Hamburg-Harburg, C-188/91, EU:C:1993:24.
} 
Direktive 85/374/EEZ u nacionalno pravo Ujedinjenog Kraljevstva Velike Britanije i Sjeverne Irske.

Direktiva 85/374/EEZ je jedna od onih direktiva koja je izazvala i još uvijek izaziva promjene na prostoru današnje Unije. Ona je rezultat kompromisa različitih interesa, prije svega proizvođača i potrošača na prostoru tadašnje Zajednice, a zatim i suprotstavljenih interesa država članica unutar Zajednice uključujući i suprotstavljene interese tadašnje Zajednice u odnosu na njezine države članice glede nadležnosti za uređenje ove vrste izvanugovornih odnosa. Tako je od same ideje ujednačavanja pravila izvanugovorne odgovornosti za štetu izazvanu neispravnim proizvodom s početka 70-ih godina prošlog stoljeća, pa sve do njenog usvajanja od Europskog vijeća 25. svibnja 1985. godine. Devetogodišnje razdoblje usvajanja Direktive obilježila su dva prijedloga iz 1976. i 1979. godine ${ }^{24,25}$ i svojevrsna ucjena Vlade Ujedinjenog Kraljevstva Velike Britanije i Sjeverne Irske glede uvrštavanja opcijskog instrumenta za obranu razvojnim rizikom. Naime, mogućnost optiranja glede isključenja odgovornosti uz pomoć obrane razvojnim rizikom bio je uvjet za njeno usvajanje. Upravo je jedan od egzoneracijskih razloga odredio, a i dalje u najvećoj mjeri određuje ovu vrstu izvanugovorne odgovornosti za štetu na današnjem prostoru Europske unije. ${ }^{26}$

Ovaj pravni akt obilježava još jedan opcijski instrument koji se odnosi na ograničenje odgovornosti proizvođača neispravnog proizvoda. Naime u čl. 16(1) Direktive uvrštena je mogućnost optiranja za države članice Unije glede najvišeg iznosa naknade štete nastale kao posljedica tjelesne povrede izazvane neispravnošću proizvoda. Državama članicama je omogućeno da ograniče najviši gornji iznos naknade štete za tjelesne povrede, s tim da donja granica iznosa naknade štete ne može biti manja od 70 milijuna eura. S druge strane najniži iznos naknade štete na imovini oštećenika koji se može zahtijevati temeljem pravila iz Direktive ograničen je na $500 €$, s tim da pojam imovina oštećenika ne obuhvaća i sam neispravni proizvod.

\subsection{Ograničenje odgovornosti prema Direktivi 85/374/EEZ}

\footnotetext{
${ }^{24}$ Proposal for a Council Directive relating to the approximation of the laws, regulations and administrative provisions of the Member States concerning liability for defective products (COM/76/372/final), Official Journal C 241, 14/10/1976 P. 9-12.

${ }^{25}$ Amendment Proposal for a Council Directive relating to the approximation of the laws, regulations and administrative provisions of the Member States concerning liability for defective products (COM/79/415/final), Official Journal C 271, 26/10/1979 P. 3-11.

${ }^{26}$ LIVAJA, J., op. cit., str. 108.
} 
Prvo ograničenje odnosi se na vrstu proizvoda na koje se primjenjuje Direktiva. Isto je urađeno posredno definiranjem pojma proizvoda $u$ čl. 2. Direktive. ${ }^{27}$ Mada je u preambuli Direktive, s kojom se na određeni način opravdava njezin pravno-politički sadržaj, navedeno „da se odgovornost bez krivnje može odnositi samo na pokretne stvari koje su industrijski proizvedene“" ograničenje odgovornosti isključivo na pokretne stvari ne odgovara suvremenom načinu života. Naime, u uvjetima postojanja različitih vrsta nepokretnosti, od građevinskih objekata za stanovanje i poslovnih građevinskih objekata pa do drugih različitih vrsta nepokretnih objekata (kao što su, primjerice, betonski električni stupovi), isključivanje odgovornosti proizvođača za takve vrste proizvoda ne može se opravdati pravno-političkim razlogom, kako to ističe europski zakonodavac ,da se odgovornost bez krivnje može odnositi isključivo na pokretne stvari koje su industrijski proizvedene“. U tom kontekstu, primjerice, isključiti odgovornost proizvođača betonskog električnog stupa koji se zbog neispravnosti prelomio i nanio štetu, ili nanošenje štete uslijed rušenja/urušavanja mosta, tunela ili drugih sličnih građevinskih objekata od općeg društvenog interesa, ne može se na takav način pravnopolitički opravdati. S druge strane, iako europski zakonodavac u preambuli Direktive navodi da se odgovornost proizvođača temeljem pravila iz ove Direktive mora odnositi i na pokretne stvari koje se upotrebljavaju za gradnju nekretnina ili se u njih ugrađuju, u Direktivi ne postoji mehanizam s kojim bi se zaštitio interes oštećenika ako je proizvođač takvog pokretnog proizvoda postupao po uputama proizvođača nepokretnog proizvoda.

Također, potrebno je spomenuti ograničenje primjene Direktive 85/374/EEZ u području nuklearnih šteta. Budući da je ovo područje regulirano međunarodnim konvencijama, europski zakonodavac je isključio primjenu Direktive na štete prouzročene nuklearnim nesrećama.

Sljedeća odredba Direktive 85/374/EEZ koja se odnosi na ograničenje odgovornosti proizvođača neispravnog proizvoda tiče se mogućnosti ugovornog ograničenja odgovornosti za štetu koja su uređena ovim pravnim aktom. Odredba čl. 12. ove Direktive izričito propisuje da se odgovornost proizvođača prema oštećenoj osobi ne može ograničiti niti isključiti. ${ }^{28}$ Iako je intencija ovog članka u prvom redu isključiti mogućnost dodatnog ograničenja, odnosno

\footnotetext{
${ }^{27}$ Direktiva 85/374/EEZ u čl. 2. propisuje sljedeće:

U svrhu ove Direktive 'proizvod' znači sve pokretnine, čak i ako su dio druge pokretnine ili nekretnine. 'Proizvod' obuhvaća električnu energiju.

${ }^{28}$ Direktiva 85/374/EEZ u čl. 12. propisuje sljedeće:

Odgovornost proizvođača u odnosu prema oštećenoj osobi, koja proizlazi iz ove Direktive, ne smije se ograničiti niti isključiti nekom odredbom koja bi ograničavala njegovu odgovornost ili ga oslobađala od odgovornosti.
} 
isključenja odgovornosti proizvođača putem nekog drugog zakonodavnog akta, u većini pravne literature isto se tumači i kao propisivanje nemogućnosti ugovornog ograničenja inter partes, odnosno isključenja odgovornosti proizvođača. Imajući u vidu da je ovo Direktiva maksimalne harmonizacije ${ }^{29}$ intencija ove odredbe ide isključivo u tom smjeru, a ne u smjeru dodatnog objašnjenja nemogućnosti ugovornog ograničenja ili isključenja odgovornosti proizvođača neispravnog proizvoda. Budući da se radi o pravilima ius cogens, mogućnost ugovornog ograničenja, odnosno isključenja odgovornosti štetnika unaprijed je isključena.

Dalje, europski zakonodavac u čl. 9. Direktive 85/374/EEZ ograničava primjenu Direktive isključivo na materijalnu štetu prouzročenu smrću ili tjelesnim ozljedama, te na štetu nastalu na imovini oštećenika koja je namijenjena za njegovu privatnu uporabu ili potrošnju, ili se je takva vrsta imovine uglavnom koristila za oštećenikovu vlastitu uporabu i potrošnju. Također, on štetu na imovini oštećenika dodatno kvantitativno ograničava, na način da određuje najnižu graničnu vrijednost štete na iznos od $500 €$. Bitno je naglasiti da je opseg naknade štete ograničen na štetu nastalu izvan samog proizvoda. Isto tako, ne treba smetnuti s uma da europski zakonodavac kroz odredbu čl. 9. Direktive posredno ograničava i njezino polje primjene, u smislu određivanja tko se sve može pojaviti u ulozi oštećenika. S ovakvom formulacijom, europski zakonodavac ograničava primjenu Direktive isključivo na potrošače. Imajući u vidu da pojam ,potrošač“ nema jednoznačno značenje, Direktiva je kroz odredbu čl. 9. posredno definirala i značenje pojma potrošač za potrebe ovog europskog zakonodavnog akta.

\subsubsection{Ograničenje odgovornosti - opcijski instrument}

Jedno od ograničenja odgovornosti prema Direktivi 85/374/EEZ povezano je s opcijskim instrumentom, kojim je državama članicama omogućeno da $\mathrm{u}$ trenutku implementacije Direktive kvantitativno ograniče odgovornost proizvođača neispravnog proizvoda za najviši iznos naknade štete zbog smrti ili tjelesne ozljede koja je prouzročena istim predmetom i jednakim nedostatkom. Imajući u vidu formulaciju odredbe čl. 16. Direktive, s kojom je državama članicama omogućeno da ograniče najviši iznos naknade štete, odnosno odgovornost proizvođača neispravnog proizvoda, s tim da tako ograničeni iznos ne smije biti niži od 70 milijuna eura, lako je zaključiti da europski zakonodavac kroz ovu odredbu u prvom

29 PETRIĆ, S., Usklađivanje europskog odštetnog prava, Zbornik radova Međunarodnog savjetovanja „Aktualnosti građanskog i trgovačkog zakonodavstva i pravne prakse“, br. VII., Mostar, 2009., str. 131. 
redu imao cilj zaštitu osiguravateljskog sektora na zajedničkom tržištu Unije. To je vidljivo iz preambule Direktive, gdje europski zakonodavac glede ovog ograničenja ističe da ta granica treba biti dovoljno visoka da jamči prikladnu zaštitu potrošača i pravilno funkcioniranje zajedničkog tržišta. Sintagma ,pravilno funkcioniranje tržišta“ podrazumijeva zaštitu, ne samo proizvodnog sektora, već i zaštitu uslužnog sektora, od kojeg je pružanje usluga raznih vrsta osiguranja (u prvom redu usluga životnih osiguranja) jedno od značajnijih gospodarskih područja i temelj stabilnosti ukupnih gospodarskih odnosa na zajedničkom tržištu Unije.

\subsection{Djelomično isključenje odgovornosti prema Direktivi 85/374/EEZ}

Pravilo o djelomičnom isključenju odgovornosti proizvođača neispravnog proizvoda $u$ europskom modelu izričito je propisano u čl. 8(2) Direktive. ${ }^{30}$ To je ujedno i jedina mogućnost za umanjenje odgovornosti proizvođača. Pravilo se odnosi na mogućnost djelomičnog oslobođenja od odgovornosti proizvođača neispravnog proizvoda, razmjerno doprinosu oštećenika, odnosno osobe za koju on odgovara ako su kumulativno ispunjene dvije pretpostavke, i to: ako je šteta nastala zbog neispravnosti proizvoda i krivnjom oštećene osobe, odnosno osobe za koju je oštećena osoba odgovorna. Ne treba smetnuti s uma da je europski zakonodavac s ovom odredbom ostavio samo mogućnost da se umanji odgovornost proizvođača neispravnog proizvoda razmjerno doprinosu oštećenika, odnosno osobe za koju oštećenik odgovara, ali ne i mogućnost potpunog isključenja odgovornosti. Pod ovu odredbu moći će se podvesti primjerice slučajevi kad je šteta nastupila zbog neispravnosti proizvoda, a oštećenik, odnosno osoba za koju on odgovara nije poduzela sve da tu štetu u granicama svojih mogućnosti umanji (npr. šteta je nastala uslijed konzumiranja neispravne hrane ili lijeka, a oštećena osoba ili osoba za koju ona odgovara nije na vrijeme potražila liječničku pomoć i sl.). Dakle, u pitanju je djelomično isključenje, odnosno umanjenje odgovornosti proizvođača neispravnog proizvoda za štetu prouzročenu takvim proizvodom, razmjerno krivnji oštećenika, odnosno osobe za koju oštećenik odgovara.

\footnotetext{
${ }^{30}$ Direktiva 85/374/EEZ u čl. 8(2) propisuje sljedeće:

Odgovornost proizvođača se može umanjiti ili poništiti, uzimajući u obzir sve okolnosti, ako je šteta nastala i zbog neispravnosti proizvoda i krivnjom oštećene osobe ili bilo koje osobe za koju je oštećena osoba odgovorna.
} 


\subsection{Isključenje odgovornosti prema Direktivi 85/374/EEZ}

Isključenje odgovornosti za štetu izazvanu neispravnim proizvodom regulirano je u čl. 7. Direktive $85 / 374 / E E Z$. U istom su izričito pobrojani egzoneracijski razlozi koji isključuju odgovornost proizvođača neispravnog proizvoda. U određenom smislu sustav egzoneracijskih razloga određuje odgovornost proizvođača neispravnog proizvoda kao svojevrsni modificirani oblik objektivne odgovornosti za štetu, koju bismo mogli podvesti pod zajednički nazivnik mješovite objektivno-subjektivne odgovornosti proizvođača neispravnog proizvoda. Međutim, nesporno je da je odgovornost proizvođača neispravnog proizvoda u nekim segmentima i stroža od klasične objektivne odgovornosti budući da ne isključuje odgovornost proizvođača unatoč doprinosu treće osobe u nastanku štete (čl. 8(2) Direktive). Kasnije ćemo vidjeti da pojedine države članice Europske unije nisu prepoznale intenciju europskog zakonodavca budući da su olakšale položaj proizvođača neispravnog proizvoda kroz pravilo o solidarnoj odgovornosti proizvođača i treće osobe. ${ }^{31}$

Prvi egzoneracijski razlog prema Direktivi 85/374/EEZ odnosi se na stavljanje neispravnog proizvoda na tržište, odnosno $u$ promet. Istim se isključuje odgovornost proizvođača i drugih osoba s njim izjednačenih u odgovornosti ako on s njihove strane nije stavljen u promet. Tako npr. ako je neispravni proizvod mimo volje proizvođača stavljen $u$ promet, u smislu da postoje okolnosti poput krađe takvog proizvoda, različitih oblika prijevare i sl., proizvođač uz pomoć ovog egzoneracijskog razloga isključuje svoju odgovornost za štetu prouzročenu takvim proizvodom. Ne treba smetnuti s uma da se oborivo predmnijeva da je neispravan proizvod u promet stavio njegov proizvođač, odnosno druga osoba u distributivnom lancu s njim izjednačena u odgovornosti ako su ispunjene ostale pretpostavke iz čl. 4. Direktive. $^{32}$

Drugi razlog za isključenje odgovornosti proizvođača neispravnog proizvoda odnosi se na trenutak stavljanja neispravnog proizvoda u promet (na tržište), točnije njime se dokazuje da u trenutku stavljanja proizvoda na tržište isti nije bio neispravan. Dokazati da proizvod nije bio neispravan u trenutku njegovog stavljanja u promet znači dokazati da je neispravnost nastupila kasnije. U ovom slučaju potrebno je činjenicu nepostojanja neispravnosti proizvoda u trenutku

\footnotetext{
${ }^{31}$ Vidi infra, str. 14.

${ }^{32}$ Direktiva 85/374/EEZ u čl. 4. propisuje sljedeće:

Oštećena osoba mora dokazati štetu, neispravnost i uzročnu vezu između neispravnosti i štete.
} 
stavljanja istog u promet dokazati na razini vjerojatnosti, kao i činjenicu neispravnosti proizvoda koja je nastupila kao posljedica djelovanja različitih okolnosti koje su nakon stavljanja proizvoda na tržište uzrokovale njegovu neispravnost. ${ }^{33}$

Treći egzoneracijski razlog odnosi se na status neispravnog proizvoda i njegovog proizvođača na tržištu. Naime, ako neispravan proizvod nije namijenjen za prodaju niti za bilo koji drugi oblik ekonomskog iskorištavanja, odnosno da ga proizvođač nije proizveo ili distribuirao tijekom svoga gospodarskog poslovanja, isti ne može imati status neispravnog proizvoda u smislu pravila iz Direktive 85/374/EEZ. Dakle, ako je takav neispravan proizvod prouzročio štetu, ista se može od proizvođača nadoknaditi samo temeljem općih ili posebnih pravila odgovornosti za štetu. Prodaja i ekonomsko iskorištavanje neispravnog proizvoda, te nastupanje proizvođača neispravnog proizvoda na tržištu su međusobno uvjetovane činjenice. U tom smislu, proizvođač koji je proizveo neispravan proizvod te ga darovao ne može se osloboditi od odgovornosti samo zato što takav proizvod nije za prodaju ako je on kao poslovni subjekt nastupao na tržištu, tj. ako ga je u sklopu svoje profesionalne djelatnosti proizveo. Zaključno, za isključenje odgovornosti proizvođača potrebno je da su kumulativno ispunjene sve pobrojane pretpostavke iz ovog egzoneracijskog razloga, tj. da proizvođač neispravan proizvod koji je prouzročio štetu nije proizveo za prodaju niti za bilo koji oblik distribucije radi ekonomskog iskorištavanja, niti ga je proizveo ili distribuirao tijekom svojeg gospodarskog poslovanja. ${ }^{34}$

Četvrti ekskulpacijski razlog kojim proizvođač isključuje odgovornost za štetu izazvanu neispravnim proizvodom odnosi se na poštivanje zadanih obveznih propisa ustanovljenih od institucija javne vlasti. Neupitno je da je proizvođač dužan poštivati zakon i postupati sukladno pozitivnim zakonskim i podzakonskim propisima. Samim tim ako je neispravnost proizvoda posljedica pridržavanja obveznih propisa izdanih od javne vlasti, proizvođač nije odgovoran za takav proizvod. Međutim, nemoguće je pravno politički opravdati istovremeno isključenje odgovornosti za takvu vrstu štete, kako za institucije javne vlasti, tako i za proizvođača neispravnog proizvoda ostavljajući oštećenika (potrošača) da se bori protiv vjetrenjača dokazujući krivnju štetnika, umjesto da mu je osigurana zaštita prava putem pravila iz ove

\footnotetext{
${ }^{33}$ Direktiva 85/374/EEZ u čl. 7(b) propisuje sljedeće:

Da je, s obzirom na okolnosti, vjerojatno da neispravnost koja je prouzročila štetu nije postojala u vrijeme kad je on stavljao proizvod na tržište ili da je neispravnost nastala poslije toga.

${ }^{34}$ Direktiva 85/374/EEZ u čl. 7(c) propisuje sljedeće:

Da on nije proizveo proizvod za prodaju, ni za bilo koji drugi oblik distribucije zbog gospodarske namjene, niti ga je proizveo ili distribuirao tijekom svoga poslovanja.
} 
Direktive. Iako je neophodno da u svakom organiziranom društvu (državi) postoje regule koje trebaju svi poštovati, u današnje suvremeno doba koje je obilježeno konstantnim promjenama, posebno u sferi znanosti i tehnike, nije rijedak slučaj da zakonodavac nije u stanju prilagoditi svoje ponašanje (najčešće iz političkih razloga) takvim promjenama, tj. svojom legislativnom djelatnošću adekvatno popratiti takve promjene, tako da ustanovljavanje takvog pravila $u$ konačnici predstavlja izvor pravne nesigurnosti. S jedne strane, nametnuti odgovornost proizvođaču za štetu izazvanu neispravnim proizvodom na načelu strože odgovornosti, a s druge strane isključiti njegovu odgovornost samo zato što se ponašao prema obveznim propisima javne vlasti, a istovremeno ne omogućiti obeštećenje od druge odgovorne osobe (javne vlasti) temeljem istih pravila, zasigurno predstavlja izvor pravne nesigurnosti i povredu načela pravednosti, te u konačnici povredu općeprihvaćenog načela zabrane uzrokovanja štete drugome (neminem laedere). Glede vrste obveznih pravila primjenjivih za isključenje odgovornosti proizvođača, na ovom je mjestu potrebno napraviti distinkciju između tzv. „,golih pravila“" (obvezni propisi koje ne prati sankcija) i onih za čije je kršenje zapriječena sankcija. U tom smislu, samo ona vrsta propisa za čiju je povredu predviđena sankcija može biti pretpostavka za isključenje odgovornosti proizvođača neispravnog proizvoda. U ostalim slučajevima, tj. kad nema zapriječene sankcije proizvođač ne podliježe obvezi poštivanja istih, te budući da za takvu svoju radnju proizvođač ne trpi pravne posljedice, isti je dužan učiniti sve što je u njegovoj moći da u trenutku stavljanja u promet proizvod bude ispravan, pa je samim tim odgovoran za štetu ako su ispunjene ostale pretpostavke iz ove Direktive. ${ }^{35}$

Peti egzoneracijski razlog iz Direktive, poznatiji kao „obrana razvojnim rizikom“, omogućava isključenje odgovornosti proizvođača i drugih osoba $s$ njim izjednačenih $u$ odgovornosti (uvoznici i distributeri) ako dokažu da stanje znanosti i tehničkog znanja u vrijeme stavljanja proizvoda u promet (na tržište) nije omogućavalo otkrivanje njegove neispravnosti. Ovaj egzoneracijski razlog po mnogo čemu je specifičan, njegova je priroda ambivalentna. Po svojoj suštini, on bi trebao biti samo jedan od ekskulpacijskih razloga s kojim proizvođač isključuje svoju odgovornost za štetu prouzročenu neispravnošću proizvoda ako dokaže da stupanj znanstvenog i tehničkog razvoja nije omogućavao otkrivanje neispravnosti. Međutim, on je prestao biti ,samo jedan od egzoneracijskih razloga“ još u postupku donošenja Direktive kojom je regulirana ova vrsta izvanugovorne odgovornosti za štetu. U jednom trenutku uvrštavanje opcijskog instrumenta za države članice glede ovog egzoneracijskog

\footnotetext{
${ }^{35}$ Više o tome LIVAJA, J., op. cit., str. 45.- 46.
} 
razloga postao je uvjet za donošenje/usvajanje Direktive 85/374/EEZ. Također, prvi slučaj koji se pojavio pred Sudom Europske unije koji se odnosio na ovu Direktivu upravo se odnosio na pravilnu implementaciju ovog instituta u zakonodavstvo Ujedinjenog Kraljevstva Velike Britanije i Sjeverne Irske. ${ }^{36} \mathrm{~S}$ druge strane, uloga ovog egzoeneracijskog razloga je takva da on u potpunosti određuje prirodu ove vrste izvanugovorne odgovornosti za štetu. Pa tako one države članice koje su uvrstile ovaj ekskulpacijski razlog u svoje zakonodavstvo u trenutku implementacije Direktive prihvatile su mješoviti objektivno-subjektivni model odgovornosti proizvođača neispravnog proizvoda. Druge države, kao što su Luksemburg i Finska, prihvatile su načelo objektivne odgovornosti proizvođača neispravnog proizvoda za ovu vrstu izvanugovorne odgovornosti za štetu. Isto tako ovaj institut odštetnog prava posredno je stvorio učinak izravne horizontalne primjene ove Direktive. Naime, prihvaćajući da je engleski zakonodavac pravilno implementirao Direktivu 85/374/EEZ, iako to nije slučaj, Sud Europske unije kroz svoju presudu u slučaju C-300/95 uvodi izravnu primjenu odredbe čl. 7(e) Direktive, namećući engleskim sudovima obvezu tumačenja domaćeg zakona onako kako je to regulirano Direktivom, a ne kako je to regulirano domaćim Consumer Protection Actom. Mutatis mutandis isto je primjenjivo i na druge države članice Unije.

Šesti egzoneracijski razlog odnosi se na proizvođača sastavnog dijela neispravnog proizvoda. Proizvođač sastavnog dijela neispravnog proizvoda može se ekskulpirati od odgovornosti za štetu od neispravnog proizvoda samo ako se neispravnost može pripisati konstrukciji proizvoda u koji je sastavni dio ugrađen ili ako je postupao prema uputama koje je dao proizvođač proizvoda. Zakonodavac razlikuje odgovornost proizvođača sastavnog dijela proizvoda u dvije različite situacije, tj. kada je neispravnost finalnog proizvoda posljedica greške u konstrukciji ili kad je neispravnost posljedica postupanja po uputama proizvođača finalnog proizvoda. U oba slučaja Direktiva ekskulpira proizvođača sastavnog dijela proizvoda. U svim drugim slučajevima proizvođač sastavnog dijela proizvoda odgovoran je u skladu s pravilima iz Direktive, odnosno prema općim pravilima odgovornosti za štetu iz nacionalnog zakonodavstva kad Direktiva upućuje na primjenu tih pravila. Ovdje dolazi do izražaja pitanje

\footnotetext{
${ }^{36}$ To je ujedno bio i prvi slučaj pred Sudom Europske unije povezan s ujednačavanjem europskog izvanugovornog odštetnog prava odgovornosti za štetu od neispravnog proizvoda. Sve ostalo što se kasnije događalo s ovim dijelom europskog odštetnog prava naslonjeno je na ovaj slučaj. On je odredio pravac razvoja, općenito, ove vrste odgovornosti za štetu u europskim okvirima, uključujući i razvoj njezinih pojedinih instituta, posebno egzoneracijskog razloga obrane razvojnim rizikom. S druge strane, ovaj slučaj ne samo da je od značaja za razvoj izvanugovorne odgovornosti za štetu, već je od značaja za opći razvoj europskog prava. Nametanjem obveze judikaturi država članica da u slučajevima izvanugovorne odgovornosti za štetu od proizvoda s nedostatkom izravno primjenjuju Direktivu, Europski sud pravde razvija doktrinu horizontalnog izravnog učinka direktive. LIVAJA, J., op. cit., str. 108.-109.
} 
granice odgovornosti proizvođača sastavnog dijela neispravnog proizvoda, u smislu njegove odgovornosti kao samostalnog proizvođača određenog sastavnog dijela proizvoda koji postupkom konstrukcije biva ugrađen u neispravan proizvod, kad neispravan finalni proizvod nije posljedica greške u konstrukciji, ${ }^{37}$ ali ne i slučaj kad isti u postupku proizvodnje sastavnog dijela proizvoda postupa prema uputama proizvođača finalnog proizvoda jer je proizvođač finalnog proizvoda u tom slučaju svakako odgovoran. Iako se može postaviti pitanje granice odgovornosti proizvođača sastavnog dijela proizvoda, ako bi isti postupajući prema uputama proizvođača finalnog proizvoda u postupku proizvodnje sastavnog dijela finalnog proizvoda povredom pravila struke napravio neispravan sastavni dio takvog proizvoda, treba li istog držati ipak odgovornim za štetu od neispravnog proizvoda $u$ granicama njegovog doprinosa $u$ nastanku štete, odgovor je negativan. Naime, bez obzira što isti nije postupao u skladu s pravilima struke u izradi sastavnog dijela proizvoda ako je postupao prema uputama proizvođača koji je u konačnici ugradnjom sastavnog dijela isti prihvatio kao ispravan, odgovornost je u potpunosti na proizvođaču finalnog proizvoda.

\subsection{Solidarna odgovornost}

Slijedi kratki osvrt na solidarnu odgovornost iz Direktive 85/374/EEZ u dijelu koji se odnosi na pravilnu implementaciju njenih pravila o odgovornosti/neodgovornosti treće osobe za štetu prouzročenu neispravnim proizvodom. Naime, europski zakonodavac je na jasan i nedvosmislen način ustanovio pravilo ,da se odgovornost proizvođača ne umanjuje ako je šteta nastala zbog neispravnosti proizvoda i radnjom ili propustom treće osobe“", s tim da ova odredba ne utječe na nacionalne zakone glede njihovih pravila o solidarnoj odgovornosti i regresu. Intencija europskog zakonodavca je očita, tj. treća osoba ni u kojem slučaju ne može biti solidarno odgovorna za štetu nastalu uslijed neispravnosti proizvoda unatoč činjenici o vlastitom doprinosu u nastanku iste.

Treća osoba se ni pod kojim okolnostima ne može pozvati na odgovornost umjesto proizvođača neispravnog proizvoda, pa makar to bilo i ustanovljavanjem posebnog pravila o solidarnoj odgovornosti proizvođača i treće osobe, kako je to učinio hrvatski zakonodavac kroz

\footnotetext{
${ }^{37} \mathrm{U}$ takvim slučajevima proizvođač sastavnog dijela finalnog neispravnog proizvoda odgovoran je za štetu prema općim pravilima iz Direktive.
} 
implementaciju Direktive u svoj novi Zakon o obveznim odnosima iz 2005. godine. ${ }^{38,39}$ Naime, kad bi bilo suprotno, tj. onako kako je to uredio hrvatski zakonodavac, u red primarno odgovornih osoba kamo pripadaju proizvođač, uvoznik i distributer, uvela bi se i svaka treća osoba bez obzira na stupanj svoga doprinosa u nastanku štete izazvane neispravnim proizvodom. Tako bi se, primjerice, stvorila situacija da bilo koja treća osoba koja svojom radnjom ili propustom doprinese u nastanku štete povezane s neispravnim proizvodom, odgovara jednako kao proizvođač, uvoznik ili distributer, iako njen doprinos u nastanku štete može biti izvan procesa nastanka neispravnog proizvoda. To bi u suštini značilo proširenje kruga odgovornih osoba izvan pravila određenih u Direktivi 85/374/EEZ iako je ona u suštini Direktiva maksimalne harmonizacije. ${ }^{40}$

U praksi Suda Europske unije zabilježeno je više slučajeva koji su se odnosili na pokušaj nametanja šireg oblika odgovornosti od onog kako je to predviđeno Direktivom 85/374/EEZ. Sve te slučajeve načelno možemo podijeliti u tri grupe. Prvoj grupi pripadaju oni slučajevi koji se odnose na pogrešnu implementaciju ove Direktive, ${ }^{41}$ drugoj grupi pripadaju slučajevi koji se odnose na pogrešno tumačenje nacionalnog zakonodavstva u kontekstu međusobnog odnosa nacionalnih zakona i Direktive 85/374/EEZ, ${ }^{42}$ dok trećoj grupi pripadaju slučajevi pogrešnog tumačenja pravila iz nacionalnog zakonodavstva kojim je implementirana ova Direktiva. ${ }^{43}$ Važno je naglasiti kako je Sud Europske unije u tim slučajevima isključio mogućnost nametanja šireg oblika odgovornosti od onog kako je to propisano Direktivom.

Međutim, novija sudska praksa nacionalnih sudova država članica Europske unije, koja je u konačnici potvrđena i od Suda Europske Unije, ukazuje na jedan novi smjer u tumačenju pojma neispravnog proizvoda. Naime, u slučajevima Boston Scientific Medizintechnik GmbH protiv AOK Sachsen-Anhalt-Die Gesundheitskasse (C-503/13) i Betriebskrankenkasse RWE $(C-504 / 13)^{44}$ kao dokaz neispravnosti proizvoda prihvaćena je činjenica „,nedokazane

\footnotetext{
${ }^{38}$ Zakon o obveznim odnosima Republike Hrvatske, NN br, 35/05, 41/08 i 125/11.

${ }^{39}$ Zakon o obveznim odnosima RH u čl. 1078. st. 4. propisuje sljedeće:

Ako je nastanku štete djelomično pridonijela treća osoba, ona odgovara solidarno s proizvođačem.

${ }^{40}$ PETRIĆ, S., op. cit., str. 131.

${ }^{41}$ Presuda Commission of the European Communities v. Kingdom of Denmark, C-327/05, EU:C:2007:409.

${ }^{42}$ Presuda Mariá Victoria Gonzáles Sánchez v. Medicina Asturiana SA, C-183/00, EU:C:2002:255.

${ }^{43}$ Presuda Centre hospitalier universitaire de Besançon v. Thomas Dutrueux, Caisse primaire d'assurance maladie du Jura, CURIA - Court of Justice of the European Union, C-495/10, EU:C:2011:869.

${ }^{44}$ Presuda Boston Scientific Medizintechnik GmbH, C-503/13, C-504/13, EU:C:2015:148.
} 
mogućnosti njegove neispravnosti“ ako se radi o proizvodu iz iste serije proizvoda ako je u ranijem ili ranijim pojedinačnim slučajevima dokazana neispravnost takve vrste proizvoda. ${ }^{45}$

\section{Američki model - product liability}

Američki product liability u mnogome je odredio razvoj ove vrste izvanugovorne odgovornosti za štetu na globalnoj razini. Općeprihvaćeno je u pravnoj literaturi da je američki product liability kolijevka razvoja pravila ove vrste odgovornosti za štetu. Isto tako, upravo je u Sjedinjenim Američkim Država, i to od Supreme Court of California po prvi put prihvaćeno načelo objektivne odgovornosti za ovu vrstu štete.

Rezimirajući povijest razvoja pravila izvanugovorne odgovornosti proizvođača neispravnog proizvoda, moguće je istaknuti nekoliko prijelomnih događaja/trenutaka. Prvi je svakako izlazak ove vrste odgovornosti za štetu izvan sfere djelovanja ugovornih odnosa. ${ }^{46}$ Drugi je sudski događaj iz 40-ih godina prošlog stoljeća, točnije epilog tog događaja, gdje kalifornijski sudac Traynor u svome izdvojenom mišljenju u slučaju Escola v. Coca-Cola Bottling Company ${ }^{47}$ ističe potrebu uvođenja načela objektivne odgovornosti za štetu nastalu od neispravnog proizvoda. Sudbina je htjela da treći prijelomni trenutak u povijesti razvoja pravila ove vrste izvanugovorne odgovornosti za štetu obilježi upravo Supreme Court of California. Naime, u predmetu Greenman v. Yuba Power Products Inc. ${ }^{48}$ kalifornijski Vrhovni sud po prvi put za proizvođača neispravnog proizvoda prihvaća odgovornost za štetu bez obzira na njegovu krivnju, tj. ustanovljava načelo objektivne odgovornosti za ovu vrstu štete. Četvrti prijelomni trenutak u povijesti razvoja izvanugovorne odgovornosti za štetu izazvanu neispravnim proizvodom je uvrštavanje $\S 402$ A u Section B - Strict Tort Liability u Restatementu (Second), ${ }^{49}$ s kojim je Američki pravni institut prihvatio načelo objektivne odgovornosti za proizvođača neispravnog proizvoda. Moglo bi se reći da je $\$ 402$ A ispunio svoju svrhu u ujednačavanju

\footnotetext{
${ }^{45}$ Više o tome, BEVANDA, M., LIVAJA, J., Građanskopravna odgovornost proizvođača neispravnog proizvoda - Presuda Suda Europske unije u spojenim predmetima C-503/13 i C-504/13 (Boston Scientific Medizintechnik), Zbornik radova Međunarodnog savjetovanja „Aktualnosti građanskog i trgovačkog zakonodavstva i pravne prakse“", br. XIV., Mostar, 2016., str. 323.-336.

${ }^{46}$ Dok je u američkoj sudskoj praksi glede odgovornosti za štetu od neispravnog proizvod došlo do promjene već 1916. godine (slučaj MacPherson v. Buick Motor Co.), engleska sudska praksa sve do slučaja Donoghue v. Stevenson iz 1932. godine ovu vrstu odgovornosti za štetu temelji na načelu relativnog djelovanja ugovora (privity of contract). Slučaj iz 1932. godine bio je prekretnica u praksi engleskih sudova. Više o tome, STAPLETON, J., Product Liability, Butterworts, London, 1994., str. 20.-21.

${ }^{47}$ Escola v. Coca-Cola Bottling Co., 24 Cal.2d 453, 150 P.2d 436 (1944).

${ }^{48}$ Greenman v. Yuba Power Products, Inc., 59 Cal.2d 57 (1963).

${ }^{49}$ American Law Institute, Restatement of the Law, Second, Torts 2d, St. Paul, Minn.: American Law Institute Publishers, 1965.
} 
primjene pravila o izvanugovornoj odgovornosti za štetu izazvanu neispravnim proizvodom na području SAD-a glede primjene načela objektivne odgovornosti na slučajeve manufacturing defecta, međutim, nikad nije postignut opći konsezus u njegovom tumačenju i primjeni na druge dvije vrste nedostataka (design defect i warning defect). S tim u vezi, Američki pravni institut putem Restatementa (Third) ${ }^{50}$ sankcionira daljnji razvitak pravila ove vrste odgovornosti za štetu, te $\mathrm{u}$ istom, sustavom numerus clausus određuje vrste nedostataka na koje će se primjenjivati Restatement of the Law, Third, Torts: Products Liability. ${ }^{51,52}$ Donošenje ovog Restatementa može se označiti kao peti prijelomni trenutak u razvoju pravila izvanugovorne odgovornosti za štetu na današnjem prostoru SAD-a.

Uzimajući u obzir specifičnosti razvoja američkog prava odgovornosti za štetu izazvanu neispravnim proizvodom kroz djelatnost najviših sudskih instanci saveznih država, a posebno kroz djelatnost Vrhovnog suda SAD-a kao najviše sudske instance u federaciji, ne čudi činjenica da je ono najprije razvijano kroz sudske predmete koji su se ticali najosjetljivijih proizvodnih sektora, onih koji se odnose na proizvodnju hrane i lijekova. Nakon hrane i lijekova na red su došli kozmetički preparati budući da su u određenom smislu bili veoma bliski lijekovima. Tako su u pojedinim slučajevima sudovi imali problema u kvalificiranju kozmetičkih proizvoda ne znajući gdje ih treba svrstati, u lijekove ili kozmetiku. Naprijed izneseno potvrđuje i činjenica da su američke savezne države najprije statutarno (zakonodavno) uređivale odgovornost za ove vrste proizvoda. Veliku ulogu u tome je odigrala Američka

\footnotetext{
${ }^{50}$ American Law Institute, Restatement of the Law, Third, Torts: Products Liability, St. Paul, Minn.: American Law Institute Publishers, 1998.

${ }^{51}$ Restatement of the Law, Third, Torts: Products Liability (Chapter 1, Topic 1, $\S 2$ - Categories of Product Defect) propisuje sljedeće:

A product is defective when, at the time of sale or distribution, it contains a manufacturing defect, is defective in design, or is defective because of inadequate instructions or warnings. A product:

(a) contains a manufacturing defect (naglasio J. L.) when the product departs from its intended design even though all possible care was exercised in the preparation and marketing of the product;

(b) is defective in design (naglasio J. L.) when the foreseeable risks of harm posed by the product could have been reduced or avoided by the adoption of a reasonable alternative design by the seller or other distributor, or a predecessor in the commercial chain of distribution, and the omission of the alternative design renders the product not reasonably safe;

(c) is defective because of inadequate instructions or warnings (naglasio J. L.) when the foreseeable risks of harm posed by the product could have been reduced or avoided by the provision of reasonable instructions or warnings by the seller or other distributor, or a predecessor in the commercial chain of distribution, and the omission of the instructions or warnings renders the product not reasonably safe.

${ }^{52}$ Nije rijedak slučaj da se u američkoj pravnoj literaturi lista nedostataka na proizvodu proširuje mimo općeprihvaćene osnovne podjele iz Restatementa (Third). Osim proizvodnog nedostatka (manufacturing defect), nedostatka u konstrukciji, odnosno dizajnu (defective in design) i nedostatka odgovarajućeg uputstva ili upozorenja (defective because of inadequate instructions or warnings), listi nedostataka pridodaju se još i nedostaci koji su posljedica razvojnog rizika (development risk defect), nedostaci koji su posljedica stanja struke u oblasti proizvodnje gdje je nastao proizvod (state of the art defect), nedostaci u oglašavanju proizvoda (post-marketing defect), te sistemski nedostaci na proizvodu (system damage/system defect). Više o tome, HOWELLS, G. G. i WEATHERILL, S., Consumer protection law, Ashgate Publishing, Ltd., Aldershot, 2005, str. 218. - 220.
} 
savezna agencija za hranu i lijekove - Food and Drug Administration (dalje u tekstu: FDA). Ne treba zaboraviti kako je upravo Frances Oldham Kelsey ${ }^{53}$ kao farmakolog u FDA odigrala ključnu ulogu u sprječavanju tzv. „,talidomidske tragedije“554 na području SAD-a. Za svoj rad i ulogu dobila je i najviše priznanje koje federalna vlada može dati za civilnu službu u SAD-u. ${ }^{55}$

\subsection{Ograničenje odgovornosti prema Restatementu (Third)}

Imajući u vidu da Restatement (Third) ustvari predstavlja svojevrsno uputstvo za sudsku praksu u američkom pravnom sustavu, pa tako i njegov dio koji se odnosi na product liability, utvrđivanje stroge granice ograničenja odgovornosti proizvođača, uključujući i druge osobe s njim izjednačene u odgovornosti, predstavljat će poteškoće svakome onom tko se odluči na takav korak. Polazeći od toga da svaka američka savezna država ima suvereno pravo da stvara građanskopravna pravila odgovornosti proizvođača neispravnog proizvoda, s tim da Vrhovni sudovi saveznih država i federalni Vrhovni sud koji se nalazi u ulozi čuvara američkog Ustava istovremeno ostvarujući i ulogu svojevrsnog vrhovnog zakonodavca, na način da kroz svoje pravorijeke u sudskim predmetima koji dođu pred njih, stvarajući vlastitu praksu naslonjenu na praksu drugih sudišta u saveznim državama i na pravnu literaturu, ustaljuju sudsku praksu (presedane) za sve slične buduće predmete (slučajeve). U takvim uvjetima sustav Restatementa u kojem je na specifičan način objedinjena sveukupna sudska praksa SAD-a predstavlja samo jedan pravni argument (pravilo) za ponašanje sudova. Unatoč svemu, današnja sudska praksa u američkom product liability nije u potpunosti ujednačena, pa tako Rastatement (Third) i dalje ostaje samo jedan opcijski instrument ili bolje rečeno soft law za američke sudove. Govoreći o

\footnotetext{
${ }^{53}$ Frances Oldham Kelsey rođena je 24. srpnja 1914. godine u Cobble Hillu na otoku Vancouver u kanadskoj provinciji British Columbia. Od 1960. godine radi kao farmakolog u američkoj Agenciji za hranu i lijekove (Food and Drug Administration - FDA). Unatoč ogromnim pritiscima proizvođača lijeka Thalidomide, odbila je dati odobrenje za stavljanje ovog lijeka u promet na području SAD-a. Presudno je u njenoj odluci bilo to da lijek nije dovoljno ispitan budući da je raspolagala određenim podacima koji su ukazivali na njegove štetne nuspojave.

${ }^{54} \mathrm{Za}$ otkrivanje talidomida, kao agensa odgovornog za pojavu deformiteta u novorođenčadi, najviše zasluga pripada dvema osobama: doktoru Widukind Lenzu u Zapadnoj Nemačkoj, koji je prvi i povezao ovaj sedativ sa fokomelijom, i farmakologu Frances Kelsey iz Agencije za hranu i lekove (FDA - Food And Drug Administration) u Sjedinjenim Američkim Državama. Oba ova stručnjaka prošla su trnovit put i podneli ogromne žrtve, kako lične, tako i profesionalne da bi dokazali ispravnost svojih stavova u vezi sa talidomidom. MANDIĆ, I. i KRAJNOVIĆ, D., Talidomidska tragedija - lekcija iz prošlosti, Timočki medicinski glasnik - TMG, 34(2009) br. 2 p.126-134, dostupno na: <http://tmg.org.rs/v340207.htm> (8.1.2018.).

${ }^{55}$ Frances Oldham Kelsey dobila je 7. kolovoza 1962. godine najviše civilno priznanje (The President's Award for Distinguished Federal Civilian Service - PADFCS) za svoj istaknuti rad u civilnoj službi SAD-a. Ovo priznanje ustanovio je američki predsjednik Dwight D. Eisenhower 27. lipnja 1957. godine. Ona je bila druga žena u američkoj povijesti koja je dobila ovo priznanje.
} 
ograničenjima odgovornosti proizvođača neispravnog proizvoda kako je to uređeno kroz Restatement (Third), ne možemo povući paralelu između njega i Direktive 85/374/EEZ u smislu obveznosti primjene njegovih pravila, kako je to u europskom modelu nametnuto članicama Unije kroz obvezu implementacije pravila iz Direktive u nacionalna zakonodavstva.

Ne ulazeći dublje u analizu product liabilitiyja za svaku američku saveznu državu zasebno, osim u onim slučajevima kad je potrebno iskazati neku specifičnost, naglasak će biti na posebnostima sustava ograničenja odgovornosti kako je to uređeno kroz Restatement (Third).

U dijelu rada u kojem se govorilo o ograničenjima odgovornosti proizvođača neispravnog proizvoda u europskom modelu istaknuto je da se prvo ograničenje odnosi na vrstu proizvoda na koje je primjenjiv sustav odgovornosti proizvođača neispravnog proizvoda iz Direktive 85/374/EEZ. Tamo je rečeno da se taj sustav odnosi isključivo na pokretne proizvode, za razliku od američkog modela koji nema takvu vrstu ograničenja. On je kao i domaći model odgovornosti proizvođača neispravnog proizvoda iz čl. 179. ZOO-a BiH primjenjiv, kako na pokretne, tako i na nepokretne proizvode.

Svojevrsno ograničenje primjene općih pravila iz Restatementa (Third) odnosi se na posebne specijalizirane proizvode odnosno tržišta, za koje sam Restatement u posebnom dijelu donosi posebna pravila za odgovornost proizvođača lijekova i drugih medicinskih proizvoda $i$ proizvođača prehrambenih proizvoda, s tim uređivač Restatementa na specifičan način uređuje još i odgovornost proizvođača sastavnog dijela neispravnog proizvoda, kao i odgovornost komercijalnog prodavatelja, odnosno distributera korištenog proizvoda. Što se tiče odgovornosti proizvođača lijekova i drugih medicinskih proizvoda, postoji jedno specifično ograničenje gdje je odgovornost proizvođača takvih proizvoda protegnuta samo na određene vrste takvih proizvoda, tj. samo na one vrste lijekova, odnosno medicinskih proizvoda koji se mogu legalno prodavati ili na drugi način distribuirati samo na temelju upute davatelja usluge zdravstvene zaštite. Iako su prema intenciji uređivača Restatementa na prehrambene proizvode primjenjiva opća pravila odgovornosti iz njega, uređivač je smatrao za shodno da dodatno pojasni neispravnost proizvoda u smislu proizvodnog nedostatka. Pa tako proizvod ima manufacturing defect ako sadrži neispravan sastojak koji uzrokuje štetu ako potrošač ne očekuje da prehrambeni proizvod sadrži spomenuti sastojak. Pod tim se podrazumijeva umetnuti neispravni sastojak tijekom procesa proizvodnje (npr. pokvareni sastojak ili sastojak koji prema deklaraciji proizvođača nije sastavni dio proizvoda) kao posljedicu greške nastale tijekom procesa proizvodnje. Za prodavatelja ili distributera neispravnog korištenog proizvoda 
odgovornost je ograničena samo na promidžbu neispravnog proizvoda uslijed nedostatka nastalog u procesu proizvodnje manufacturing defect, s tim da prodavateljeva promidžba dovodi do toga da osoba u ulozi kupca očekuje da korišteni proizvod ne predstavlja veću opasnost od takvog neispravnog novog proizvoda.

Sljedeće ograničenje odgovornosti prema Restatementu (Third) odnosi se na svojevrsne pretpostavke za odgovornost sljednika neispravnog proizvoda koji je prodao njegov prednik u sklopu svoje komercijalne djelatnosti. Iako je izričito određena odgovornost sljednika, ona je i ograničena na način da su $\S 12$ Restatementa (Third) taksativno navedene alternativne pretpostavke za njegovu odgovornost. ${ }^{56}$

Isto tako, kako je to uobičajeno za ovu vrstu pravila izvanugovorne odgovornosti za štetu, i u američkom product liabilityju odgovornost proizvođača ograničena je na štetu nastalu na osobi i imovini oštećenika izvan samog neispravnog proizvoda. Šteta nastala na samom neispravnom proizvodu može se zahtijevati temeljem pravila ugovorne odgovornosti za materijalne nedostatke prodane stvari.

Zaključno, budući da je odgovornost proizvođača $\mathrm{u}$ američkom modelu product liabilityja isprepletena s općim pravilima odgovornosti za štetu koja se temelji na subjektivnoj odgovornosti štetnika, osim u slučajevima odgovornosti za manufacturing defect koja počiva na načelu objektivne odgovornosti proizvođača, odgovornost proizvođača podvrgnuta je ograničenjima koja su općenito primjenjiva na slučajeve tort of negligence. Naravno, takva vrsta ograničenja primjenjiva je samo na one situacije za koje ne postoje pravila lex specialis, odnosno posebna pravila za product liability.

\subsection{Isključenje odgovornosti prema Restatementu (Third)}

\footnotetext{
${ }^{56}$ Restatement of the Law, Third, Torts: Products Liability (Chapter 3, § 12 - Liability of Successor for Harm Caused by Defective Products Sold Commercially by Predecessor) propisuje sljedeće:

A successor corporation or other business entity that acquires assets of a predecessor corporation or other business entity is subject to liability for harm to persons or property caused by a defective product sold or otherwise distributed commercially by the predecessor if the acquisition:

(a) is accompanied by an agreement for the successor to assume such liability; or

(b) results from a fraudulent conveyance to escape liability for the debts or liabilities of the predecessor; or

(c) constitutes a consolidation or merger with the predecessor; or

(d) results in the successor becoming a continuation of the predecessor.
} 
Budući da je koncept pravila o odgovornosti za štetu izazvanu neispravnim proizvodom u američkom pravu odgovornosti za štetu uređen kroz Restatement (Third), na način da je na samom početku dana definicija nedostataka na proizvodu, dijeleći ih na manufacturing defect, design defect i warning defect, cjelokupni sustav ograničenja i isključenja odgovornosti proizvođača neispravnog proizvoda $u$ potpunosti je podređen upravo takvoj podjeli neispravnosti proizvoda.

Sve do presedana kalifornijskog Vrhovnog suda u predmetu Greenman v. Yuba Power Products Inc., u američkom pravu odgovornosti za štetu izazvanu neispravnim proizvodom odgovornost proizvođača takvog proizvoda temeljila se na njegovoj subjektivnoj odgovornosti, točnije njegovoj predmnijevanoj krivnji za neispravnost proizvoda, a samim tim i njegovoj krivnji za štetu izazvanu neispravnim proizvodom. Presuđujući u korist oštećenika, u ovom slučaju američka sudska praksa prihvaća načelo objektivne odgovornosti za štetu izazvanu neispravnim proizvodom. Od samog početka, primjena ovog načela na vrstu nedostatka koji je nastao kao posljedica propusta u proizvodnji neispravnog proizvoda (manufacturing defect) nije upitna. S druge strane, problem primjene načela objektivne odgovornosti na druge dvije vrste nedostataka - design defect i warning defect postoji od samog početka. Recentna američka pravna literatura, uključujući i sudsku praksu, složna je kako je primjena načela objektivne odgovornosti ograničena samo na jednu vrstu nedostataka, a to su nedostaci nastali kao posljedica propusta u proizvodnji, odnosno manufacturing defect. I druge dvije vrste nedostataka počivaju na strožoj odgovornosti proizvođača takvih proizvoda imajući u vidu teret dokazivanja, tj. predmnijevanu krivnju proizvođača, međutim, pravna priroda odgovornosti proizvođača za ove druge dvije vrste nedostataka na proizvodu temelji se na njegovoj krivnji.

S tim u vezi, analizirajući načine isključenja odgovornosti proizvođača, iste možemo razvrstati u tri grupe. U prvu grupu spadaju ekskulpacijski razlozi koji su primjenjivi/odnose se na manufacturing defect. Drugom grupom su obuhvaćeni egzoneracijski razlozi primjenjivi na slučajeve design defecta. Dok u treću grupu egzoneracijskih razloga možemo svrstati one koji isključuju odgovornost proizvođača za štetu prouzročenu nedostatkom upozorenja, odnosno uputstva (warning defect).

Imajući u vidu da je na odgovornost proizvođača za proizvodni nedostatak (manufacturing defect) primjenjivo načelo objektivne odgovornosti, u egzoneracijske razloge mogu se ubrojiti isključivo oni koji su primjenjivi za načelo objektivne odgovornosti, tj. viša sila, radnja trećeg i radnja oštećenika. Međutim, ova lista egzoneracijskih razloga mora biti na 
specifičan način ograničena/modificirana budući da se radi o posebnoj vrsti odgovornosti. Naime, imajući u vidu da je osim postojanja neispravnog proizvoda temelj odgovornosti proizvođača stavljanje takvog proizvoda na tržište, odnosno u promet, ${ }^{57}$ a s druge strane da proizvođač odgovara za svoje radnike, lista egzoneracijskih razloga za ovu vrstu nedostataka svedena je u stvarnosti samo na višu silu. Regresni odnos između proizvođača i radnika nije predmet pravila ove vrste odgovornosti. Radnja oštećenika u ovom slučaju izlazi izvan sfere štete koja je posljedica neispravnosti proizvoda i svodi se na njegov doprinos u sprječavanju posljedica štete prouzročenih takvim proizvodom koje je on mogao spriječiti, odnosno predvidjeti (npr. zakašnjelo javljanje liječniku i sl.).

Što se tiče druge vrste nedostatka poznatijeg kao nedostatak u konstrukciji, odnosno dizajnu (design defect), lista egzoneracijskih razloga znatno je šira. Naime, iako se kroz Restatement (Second) naizgled činilo da je u njemu prihvaćena objektivna odgovornost za sve vrste nedostataka, od samog početka prihvaćanja njegovih pravila očito je da se u slučajevima design defecta radi o odgovornosti proizvođača utemeljenog na njegovoj krivnji. Sama činjenica da je za ovu vrstu nedostatka prihvaćena obrana stanjem struke state of the art defence ${ }^{58}$ govori da je odgovornost proizvođača utemeljena na krivnji. Bez obzira što su u ovom slučaju na isključenje odgovornosti primjenjiva stroža pravila, u smislu istraživanja najvišeg dostupnog znanja iz određene struke, ova je odgovornost subjektivne prirode. Razumni alternativni dizajn postaje mjerilo neispravnog dizajna - design defecta.

Isto tako, egzoneracijski razlozi za treću vrstu nedostataka u američkom modelu odgovornosti za štetu izazvanu neispravnim proizvodom iz Restatementa (Third) određuju pravnu prirodu odgovornosti za ovu vrstu nedostatka. Budući da se odgovornost proizvođača za ovu vrstu nedostatka temelji na propustima u davanju upozorenja za poznate rizike, odnosno

\footnotetext{
${ }^{57}$ Ukoliko proizvođač u sklopu svoje redovne komercijalne djelatnosti nije stavio proizvod u promet, isti se ne može ni pozvati na odgovornost prema pravilima product liability.

${ }^{58} \mathrm{U}$ razvoju state of the art defence razlikuju se dvije faze. U prvoj fazi ona se temelji na građanskom deliktu nepažnje (tort of negligance), odnosno ponašanju štetnika u projektiranju (konstrukciji) i umješnosti proizvodnje nekog proizvoda. U tom razdoblju ponašanje štetnika u kontekstu projektiranja $\mathrm{i}$ umješnosti u proizvodnji cijenjeno je u odnosu na standarde koje je struka iz određenog proizvodnog područja prihvatila za takve vrste proizvoda. State of the art defence podrazumijeva suglasno ponašanje štetnika s odgovarajućim standardima, ali ne i zahtjev za njegovim prevladavanjem u smislu stvaranja alternativnog (boljeg) proizvoda. Kasnije, s prihvaćanjem objektivne odgovornosti za štetu od neispravnog proizvoda, američka sudska praksa prihvaća donekle drugačiji pristup u ekskulpaciji od odgovornosti za štetu od takvog proizvoda. U slučajevima građanskog delikta koji se temelji na strict liability, na način kako je to prihvaćeno u Restatementima, state of the art defence i dalje se temelji na suglasnosti sa općeprihvaćenim standardima koje je potrebno poštovati u proizvodnji, tj. konstrukciji i izradi proizvoda. Ali za razliku od state of the art defence kakva je prihvaćena u građanskim deliktima nepažnje, odgovornost proizvođača se ne isključuje ukoliko nije poduzeo sve što je u njegovoj moći, uključujući i primjenu najvišeg stupnja znanstveno-tehničkog znanja u otklanjanju nedostatka na proizvodu. LIVAJA, J., op. cit., str. 76.-77.
} 
uputstava o načinu uporabe/konzumiranja određenog proizvoda, isključenje njegove odgovornosti, odnosno egzoneracijski razlozi nisu identični onima za design defect. Samim tim što neki proizvod ima određenu uputu za uporabu ili upozorenje ne znači da je proizvođač automatski oslobođen za nedostatak u dizajnu, odnosno konstrukciji. Naime, davanje apstraktnog upozorenja bez njegovog stavljanja u kontekst stvarnih opasnosti povezanih s njegovom uporabom ili konzumiranjem, ne oslobađa proizvođača odgovornosti za štetu izazvanu neispravnim proizvodom.

\section{Domaći model de lege lata i de lege ferenda}

Odgovornost proizvođača neispravnog proizvoda u Bosni i Hercegovini danas se temelji na odredbi čl. 179. važećeg Zakona o obveznim odnosima. Do sada je bilo nekoliko pokušaja donošenja novog Zakona o obveznim odnosima, međutim, zbog manjkavosti političke volje za rješenjem ovog pitanja, do danas to nije urađeno. Osim političke volje, upitno je i pitanje nadležnosti donošenja novog zakona. Naime, Aneks IV Daytonskog mirovnog sporazuma, točnije Ustav Bosne i Hercegovine ${ }^{59}$ izričito je utvrdio raspodjelu nadležnosti između entiteta i države. ${ }^{60}, 61 \mathrm{U}$ toj raspodjeli, nesporna je činjenica da je nadležnost za uređivanje građanskopravnih odnosa stavljena u nadležnost entiteta, pa je sama procedura pokušaja nametanja rješenja bez suglasnosti entiteta unaprijed osuđena na propast. To se pokazalo točnim i kod pokušaja usvajanja posljednjeg prijedloga novog Zakona o obveznim odnosima iz 2010. godine. ${ }^{62}$ Iako je jedan od preduvjeta u postupku približavanja Bosne i Hercegovine Europskoj uniji, između ostalog, i usvajanje novog Zakona o obveznim odnosima, u Deklaraciji za provedbu mira u Bosni i Hercegovini od 23. i 24. svibnja 2000. godine (tzv. briselska

\footnotetext{
${ }^{59}$ Ustav Bosne i Hercegovine. Sarajevo. OHR, Office of the High Representative.

${ }^{60}$ Ustav Bosne i Hercegovine u čl. III(1) propisuje da su sljedeći poslovi u nadležnosti institucija Bosne i Hercegovine, i to: vanjska politika; vanjskotrgovinska politika; carinska politika; monetarna politika; financiranje institucija i međunarodnih obveza Bosne i Hercegovine; politika useljavanja, izbjeglica i azila, kao i donošenje propisa o tome; provođenje međunarodnih i međuentitetskih krivičnopravnih propisa, uključujući i odnose s Interpolom; postavljanje i rad zajedničkih i međunarodnih komunikacijskih uređaja; donošenje propisa o transportu među entitetima; kontrola zračnog prometa.

${ }^{61}$ Ustav Bosne i Hercegovine u čl. III(3)a. propisuje sljedeće:

Sve vladine funkcije i ovlasti, koje po ovom Ustavu nisu izričito dodijeljene institucijama Bosne i Hercegovine, pripadaju entitetima.

${ }^{62}$ Prijedlog Zakona o obveznim odnosima, predlagatelj: Vijeće ministara BiH, zakon broj: 01,02-02-5-3/10 od 18.1.2010. (prvo čitanje na 71. sjednici Zastupničkog doma Parlamentarne skupštine BiH održanoj 3.2.2010., i u nastavku 71. sjednice održane 10.2.2010.). Parlamentarna skupština Bosne i Hercegovine, dostupno na:

$<$ http://www.parlament.ba/session/SessionDetails?id=1657\&ConvernerId=1\&lang=hr> (8.1.2018.).
} 
deklaracija), ${ }^{63}$ prihvaćeno je, između ostalog, samo usuglašeno donošenje Zakona o obveznim odnosima od entitetskih skupština, a ne i obvezno donošenje krovnog zakona na razini države. ${ }^{64}$

\subsection{Ograničenje i isključenje odgovornosti proizvođača stvari s nedostatkom}

\section{Slično kao što je to urađeno u Restatementu (Second), ${ }^{65}$ odgovornost proizvođača stvari} s nedostatkom iz čl. 179. Zakona o obveznim odnosima Bosne i Hercegovine uređena je kroz odredbu jednog članka. ${ }^{66}$ Imajući u vidu da se odredba čl. 179. nalazi u odjeljku u kojem je regulirana odgovornost za opasnu stvar, odnosno djelatnost, opći instituti ove vrste odgovornosti primjenjivi su i na odgovornost proizvođača stvari s nedostatkom, uključujući i opća pravila odgovornosti za štetu, poput instituta zastare i sl.

Iz odredbe čl. 179. naizgled se čini da proizvođač stvari s nedostatkom odgovara neograničeno. ${ }^{67}$ Međutim, odredba stavka 2. ovog članka ograničava odgovornost proizvođača

\footnotetext{
${ }^{63}$ Declaration of the Peace Implementation Council, OHR - Ured visokog predstavnika, dostupno na: $<$ http://www.ohr.int/?p=54079\&print=pdf $>$ (8.1.2018.).

${ }^{64}$ Annex to the PIC Declaration: required actions, između ostalog sadrži i sljedeće:

The following legislation must be adopted in a harmonised manner by the Entity Parliamentary Assemblies: Law on Land Registry (December 2000), Law on Obligations and Contracts (June 2001), Law on Public Procurement (December 2000), Law on Budget Transparency (December 2000) and Law on Public Corporate Transparency Law (October 2000). OHR - Ured visokog predstavnika, dostupno na: <http://www.ohr.int/?p=54075\&print=pdf> (8.1.2018.).

${ }^{65}$ Restatement (Second) u $§ 402 \mathrm{~A}$ - Special Liability of Seller of Product for Physical Harm to User or Consumer, propisuje sljedeće:

(1) One who sells any product in a defective condition unreasonably dangerous to the user or consumer or to his property is subject to liability for physical harm thereby caused to the ultimate user or consumer, or to his property, if
}

a) the seller is engaged in the business of selling such a product, and

b) it is expected to and does reach the user or consumer without substantial change in the condition in which it is sold.

(2) The rule stated in Subsection (1) applies although

a) the seller has exercised all possible care in the preparation and sale of his product, and

b) the user or consumer has not bought the product from or entered into any contractual relation with the seller.

Caveat:

The Institute expresses no opinion as to whether the rules stated in this Section may not apply

(1) to harm to persons other than users or consumers;

(2) to the seller of a product expected to be processed or otherwise substantially changed before it reaches the user or consumer; or

(3) to the seller of a component part of a product to be assembled.

66 Vidi supra, str. 3., bilj. 6.

${ }^{67}$ Pravo na naknadu štete uzrokovane nedostatkom proizvoda koji je stavljen u promet ima svaka osoba koja je štetu pretrpjela, pod uvjetom da ne postoje razlozi za isključivanje ili ograničenje odgovornosti proizvođača. To pravo, prije svega, ima posljednji kupac stvari s nedostatkom, zatim svatko tko je takvu stvar upotrebljavao, nezavisno da li je za to bio ovlašten, te oštećenik kojem je od nedostatka stvari nastala šteta na drugim dobrima, iako on sam osobno i nije bio sa stvari ni u kakvom kontaktu. Međutim, da bi oštećenik imao pravo na naknadu 
za opasna svojstva stvari, ${ }^{68}$ na način da propisuje blaži oblik odgovornosti proizvođača, namećući istom subjektivnu odgovornost ako nije poduzeo sve što je potrebno da predvidivu štetu spriječi poduzimanjem adekvatne mjere. Zakonodavac u prvom redu ističe mjeru upozorenja i sigurnu ambalažu, ali budući da je sustav adekvatnih mjera postavljen alternativno, popis istih se ne iscrpljuje, pa će u obzir doći bilo koja mjera/radnja proizvođača s kojom je mogao spriječiti buduću predvidivu štetu stvari s opasnim svojstvima.

Budući da ZOO BiH nema posebne odredbe o opsegu i visini naknade štete prouzročene od stvari s nedostatkom, ako izuzmemo pravila o ugovornoj odgovornosti za materijalne nedostatke prodane stvari, sudska praksa je bila primorana tumačeći odredbu čl. 179. u kontekstu općih pravila o odgovornosti za štetu izgraditi posebna pravila o opsegu i visini naknade štete za ovu vrstu izvanugovorne odgovornosti za štetu. Tako je prihvaćeno, odnosno odgovornost proizvođača stvari s nedostatkom iz čl. 179. ograničena je isključivo na štetu izvan same stvari s nedostatkom. U tom smjeru ide i stav Građanskog odjela Vrhovnog suda Hrvatske od 28. lipnja 1985. godine koji jasno i nedvosmisleno razlikuje odgovornost proizvođača stvari s nedostatkom od odgovornosti prodavatelja, na način da se odgovornost proizvođača koji je ujedno i prodavatelj može zahtijevati, kako na temelju čl. 179., tako i na temelju čl. 478., dok se u slučajevima u kojima proizvođač nije istovremeno i prodavatelj, on može pozvati na odgovornost samo na temelju čl. 179. Zakona o obveznim odnosima. ${ }^{69}$

Imajući u vidu da sustav odgovornosti proizvođača stvari s nedostatkom nema vlastita pravila o isključenju odgovornosti proizvođača neispravne stvari, na isti se primjenjuju pravila o isključenju odgovornosti za opasnu stvar i opasnu djelatnost ${ }^{70}$ u dijelu odredbe čl. 179. prema kojoj je proizvođač odgovoran prema načelu objektivne odgovornosti, dok su na dio odredbe

štete po članku 179. Zakona o obveznim odnosima potrebno je da je šteta nastala pri uobičajenoj upotrebi stvari, prema namjeni za koju je proizvođač stavio stvar u promet. Pravni stav Kantonalnog suda u Sarajevu, objavljen $u$ Biltenu sudske prakse Kantonalnog suda u Sarajevu, br. 3/2001, str. 22.

${ }^{68}$ Opasna svojstva ima stvar koja nema proizvodnih nedostataka, ali joj nedostaje nužna valjana uputa za redovitu uporabu ili rukovanje zbog čega ona čini opasnu stvar. GORENC, V., Zakon o obveznim odnosima s komentarom, RRiF-plus d.o.o., Zagreb, 1998., str. 254.

${ }^{69}$ Stav Građanskog odjela Vs (V/85) od 28.6.1985. PSP-28/58. CRNIĆ, I., Naknada štete, odgovornost za štetu i popravljanje štete, pregled aktualne sudske prakse, Organizator, Zagreb, 1998., str. 66.

${ }^{70} \mathrm{ZOO} \mathrm{BiH}$ u čl. 177. propisuje sljedeće:

(1) Imalac se oslobađa odgovornosti ako dokaže da šteta potječe od nekog uzroka koji se nalazio izvan stvari, a čije se djelovanje nije moglo predvidjeti, ni izbjeći ili otkloniti.

(2) Imalac stvari oslobađa se odgovornosti i ako dokaže da je šteta nastala isključivo radnjom oštećenika ili treće osobe, koju on nije mogao predvidjeti i čije posljedice nije mogao izbjeći ili otkloniti.

(3) Imalac se oslobađa odgovornosti djelomično ako je oštećenik djelomično pridonio nastanku štete.

(4) Ako je nastanku štete djelomično pridonijela treća osoba, ona odgovara oštećeniku solidarno s imaocem stvari, a dužna je snositi naknadu razmjerno težini svoje krivnje.

(5) Osoba kojom se imalac poslužio pri upotrebi stvari ne smatra se trećom osobom. 
koja se odnosi na odgovornost za opasna svojstva stvari i koja se zasniva na subjektivnoj odgovornosti proizvođača za predvidivu štetu, primjenjiva, kako pravila iz čl. 177., tako i opća pravila odgovornosti za štetu utemeljena na načelu subjektivne odgovornosti štetnika. ${ }^{71}$ Opća pravila odgovornosti za štetu primjenjiva na st. 2. čl. 179. Zakona odnose se na ponašanje dobrog gospodarstvenika glede poduzimanja potrebnih mjera i radnji s ciljem sprečavanja nastanka štete stvari s opasnim svojstvima.

\subsection{Ograničenje i isključenje odgovornosti proizvođača de lege ferenda}

Oba dosadašnja teksta budućeg Zakona o obveznim odnosima Bosne i Hercegovine ${ }^{72} \mathrm{u}$ dijelu koji se odnosi na odgovornost proizvođača za neispravan proizvod bitno se ne razlikuju u odnosu na tekst sadržaja Direktive 85/374/EEZ. Naime, isti skoro identično preslikavaju odredbe Direktive u nacrt/prijedlog novog Zakona o obveznim odnosima Bosne i Hercegovine. Osnovna pravila o ograničenju i isključenju odgovornosti proizvođača za štetu izazvanu neispravnim proizvodom identična su onima iz Direktive. Slijedi osvrt na neke terminološke specifičnosti, te na svojevrsno dodatno ograničenje odgovornosti proizvođača sastavnog dijela neispravnog proizvoda.

Terminološka neusklađenost iz Nacrta Zakona o obveznim odnosima iz 2003. s Direktivom 85/374/EEZ ispravljena je u prijedlogu Zakona iz 2010. godine na način da je termin ,greška“ na proizvodu zamijenjena uobičajenim pojmom „neispravan proizvod“.

Prijedlog novog ZOO-a BiH ide utabanom stazom koju je prokrčila Direktiva 85/374/EEZ definirajući skoro na identičan način pojmove proizvoda i neispravnog proizvoda. Međutim, iako je očito da je Zakon o obveznim odnosima Republike Hrvatske bio model

${ }^{71}$ Proizvođač stvari sa nedostatkom može se osloboditi odgovornosti za štetu od takve stvari ako dokaže:

1. Da je šteta nastupila isključivo radnjom oštećenika, jer stvar nije upotrebljavao na uobičajen način ili se nije pridržavao uputstva o upotrebi stvari;

2. Ako je oštećenik pri nabavci ili upotrebi stvari znao za nedostatak stvari koji mu može uzrokovati štetu i usprkos tome je kupio, odnosno upotrijebio;

3. Ako je do štete došlo iz uzroka koji su izvan stvari s nedostatkom. Kako je odgovornost proizvođača izvanugovorna i zakonom određena, on ne može posebnim klauzulama prilikom stavljanja u promet proizvoda svoju odgovornost isključiti ili ograničiti. Samo na temelju zakona proizvođač može biti oslobođen odgovornosti ili ona može biti djelomično ograničena za štetu od stvari sa nedostatkom.

Pravni stav Kantonalnog suda u Sarajevu, objavljen u Biltenu sudske prakse Kantonalnog suda u Sarajevu, br. 3/2001, str. 22.

${ }^{72} \mathrm{U}$ pitanju su nacrt Zakona o obveznim odnosima iz 2003. godine i prijedlog Zakona o obveznim odnosima iz 2010. godine. 
pravilo za bosanskohercegovačkog zakonodavca, te da se zbog toga mogla potkrasti neadekvatna definicija proizvoda iz čl. 202. prijedloga Zakona, ${ }^{73}$ ali je nejasno zašto domaći zakonodavac i dalje inzistira na istoj definiciji iako je hrvatski zakonodavac uvidjevši nedostatak takve definicije proizvoda izvršio izmjenu čl. 1074. ZOO-a RH. ${ }^{74}$ Naime, uvrštavanje pojma „samostalni dio“ u zakonsko određenje pojma proizvoda vjerojatno će prouzročiti mnoge nejasnoće u tumačenju i primjeni ove odredbe. U tom smislu posebno će doći do izražaja oni slučajevi u kojima neispravni proizvod biva ugrađen u drugi neispravni proizvod kao njegov sastavni dio. Ako bude zadržana ovakva definicija pojma proizvoda, bosanskohercegovačka sudska praksa preuzet će složenu zadaću da u svakom konkretnom slučaju mora utvrđivati, ne samo neispravnost određenog proizvoda, već i granice njegove samostalnosti ako je ugrađen u drugi neispravni ili ispravni proizvod.

\section{Zaključak}

Analizirajući pravila o odgovornosti proizvođača neispravnog proizvoda iz europskog, američkog i domaćeg modela, glede pravila o ograničenju i isključenju odgovornosti proizvođača stavljenih u kontekst potrebe zaštite interesa današnjeg potrošača, moguće je iskazati nekoliko njihovih bitnih obilježja stavljajući ih u međusobni odnos. Tako, imajući u vidu da u današnjem domaćem modelu odgovornosti proizvođača stvari s nedostatkom nema ograničenja glede vrste proizvoda u smislu njegove pokretnosti/nepokretnosti, uključujući i nepostojanje ograničenja na materijalnu/nematerijalnu štetu, kao i pravila o zastari potraživanja iz izvanugovornog odnosa naknade štete, može se konstatirati da je u ovom dijelu današnji domaći model odgovornosti iz čl. 179. ZOO-a BiH mnogo povoljniji za potrošača, odnosno oštećenika. Također, vrijedno je istaknuti i nepostojanje ograničenja glede mogućnosti obeštećenja temeljem pravila iz čl. 179. za svakog oštećenika, bez obzira na njegov status/svojstvo fizičke ili pravne osobe. Za razliku od Direktive koja ograničava mogućnost

\footnotetext{
${ }^{73}$ Prijedlog ZOO-a BiH u čl. 202. propisuje sljedeće:

(1) Proizvod u smislu ovoga Zakona je bilo koja pokretna stvar, kao i samostalni dio ugrađen u neku pokretnu i nepokretnu stvar.

(2) Proizvod su električna i drugi oblici energije.

${ }^{74}$ ZOO RH u čl. 1074. propisuje sljedeće:

1) Proizvod je bilo koja pokretna stvar, pa i onda kad je ugrađena u neku drugu pokretnu ili nepokretnu stvar.

2) Proizvod su električna i drugi oblici energije.
} 
obeštećenja samo za fizičke osobe, što je prema intenciji ovog pravnog akta istoznačno sa statusom potrošača, u domaćem modelu nema takve zapreke.

Nesporna je činjenica da Bosna i Hercegovina na svom putu k Europskoj uniji mora prilagoditi domaće zakonodavstvo pravnoj stečevini Europske unije (acquis communautaire), ali je nejasno zašto se tako lako odricati vrijednih instituta, poput čl. 179., u uvjetima kad isti još uvijek ima svoju vrijednost, odnosno ispunjava određene pravno-političke ciljeve suvremenog društva, kao što su zaštita interesa potrošača glede nematerijalne štete prouzročene neispravnim proizvodom, a ponajviše u smislu zaštite interesa pravnih osoba u slučajevima kada su pretrpjele štetu od neispravnog proizvoda. Naime, prepoznajući ovu mogućnost, pojedine države zapadnog Balkana ${ }^{75,76}$ zadržale su prijašnji model odgovornosti proizvođača stvari s nedostatkom, istovremeno s implementacijom Direktive u nacionalne pravne sustave. Zadržavanjem čl. 179. aktualnog Zakona o obveznim odnosima Bosna i Hercegovina svrstala bi se u red onih zemalja nastalih raspadom Socijalističke Federativne Republike Jugoslavije, koje su uz istovremeno prepoznavanje suvremenih trendova $\mathrm{u}$ području ove vrste izvanugovorne odgovornosti za štetu zadržale i dosadašnji sustav, koji bi bio primjenjiv u slučajevima naknade nematerijalne štete ili naknade štete gdje se u ulozi oštećenika pojavljuje pravna osoba. S tim u vezi, postaje očito da se Republika Hrvatska donošenjem novog Zakona o obveznim odnosima ${ }^{77}$ olako odrekla jednog uistinu vrijednog dijela instituta odštetnog prava, uobličenog u čl. 179. bivšeg Zakona o obveznim odnosima.

S druge strane, potrebno je navesti i prednosti europskog modela iz Direktive 85/374/EEZ glede pravila o ograničenju i isključenju odgovornosti proizvođača neispravnog proizvoda. Tako, u dijelu pravila koja se odnose na odgovornost treće osobe u doprinosu nastanka štete izazvane neispravnim proizvodom, europski zakonodavac izričito propisuje da se odgovornost proizvođača ne ograničava, odnosno njegova se odgovornost ne može umanjiti ili isključiti. Dio odredbe koja se odnosi na primjenu pravila solidarne odgovornost iz novog ${ }^{78}$

\footnotetext{
${ }^{75}$ Pojam zapadni Balkan ne može se naći ni u jednom boljem politološkom rječniku. Riječ je o novom pojmu, kojim se pokušava opisati strategija EU-a prema regiji bivše Jugoslavije s izuzetkom Slovenije i dodatkom Albanije. MILARDOVIĆ, A., Zapadni Balkan - pojam, ideje i dokumenti o rekonstrukciji Balkana u procesu globalizacije, Pan liber, Osijek - Zagreb - Split, 2000., str. 24.

${ }^{76}$ Sve države nastale raspadom SFRJ, osim Republike Hrvatske, u svojem pozitivnom zakonodavstvu zadržale su model instituta Odgovornosti proizvođača stvari s nedostatkom iz čl. 179. Zakona o obveznim odnosima iz 1978. godine, s tim da su ga neke države, kao što je primjerice Republika Slovenija, nadopunile institutom odgovornosti za štetu od neispravnog proizvoda iz Direktive 85/374/85/EEZ.

77 Zakon o obveznim odnosima Republike Hrvatske, NN br. 35/05, 41/08 i 125/11.

${ }^{78}$ Prijedlog ZOO-a BiH u čl. 205. st. 2. i 3. propisuje sljedeće:

(2) Odgovornost proizvođača se ne umanjuje kad je šteta prouzrokovana neispravnim proizvodom i istovremenom radnjom nekog trećeg.
} 
domaćeg zakonodavstva ni u kojem slučaju ne proširuje odgovornost treće osobe, kako je to prihvaćeno u novom ZOO-u RH. Intencija europskog zakonodavca nije ni u kojem slučaju proširenje kruga odgovornih osoba kroz nacionalna pravila o solidarnoj odgovornosti, već upravo suprotno, ograničenje odgovornosti za štetu od neispravnog proizvoda na proizvođača takvog proizvoda.

Što se tiče pravila o isključenju odgovornosti iz Direktive, ista su suvremenija u odnosu na domaći model odgovornosti, te više odgovaraju potrebama suvremenog društva u današnjim uvjetima masovne industrijske proizvodnje i razvijenog prometa. Naravno, pod tim se ne podrazumijevaju sva pravila o isključenju odgovornosti proizvođača neispravnog proizvoda, već u prvom redu prihvaćanje mogućnosti obrane razvojnim rizikom. Pravilo o neodgovornosti proizvođača sastavnog dijela nepokretnog proizvoda ni u kojem slučaju ne ispunjava pravnopolitičke ciljeve bilo koje državne zajednice. Isključiti odgovornost proizvođača nepokretnih proizvoda u uvjetima kad građevinski sektor predstavlja značajan dio ukupnih proizvodnih odnosa i u uvjetima kada smo svjedoci događaja čestog urušavanja neispravnih građevinskih objekata, najčešće zbog potresa, u najmanju ruku je neodgovorno prema potrošačima, a u krajnosti narušava i proklamirano načelo ravnomjerne raspodjele tereta odgovornosti između proizvođača i potrošača. Isto tako, isključiti odgovornost za štetu od neispravnog proizvoda iz razloga što je proizvođač postupao/postupio prema obveznim propisima koje su izdale javne vlasti, uz istovremeno neomogućavanje obeštećenja potrošača od stvarnog štetnika, odnosno odgovorne osobe, narušava načelo ravnomjerne raspodjele tereta odgovornosti proklamirano u preambuli Direktivi 85/374/EEZ.

Kad je u pitanju američki product liability važno je naglasiti da on u potpunosti nastavlja razvoj osnovnih načela iz pravila ove vrste izvanugovorne odgovornosti za štetu započetih 60ih godina prošlog stoljeća. Naime, prihvaćajući od samog početka trodiobu nedostataka na proizvodu na manufacturing defect, design defect i warning defect, američka pravna praksa i literatura izgrađuju sustav ograničenja i isključenja odgovornosti proizvođača i drugih osoba s njim izjednačenih u odgovornosti na temeljima mješovite subjektivno-objektivne odgovornosti štetnika.

(3) Odredbe člana 201. do 207. ovog zakona ne isključuju i ne ograničavaju primjenu odredaba o naknadi nematerijalne štete i o podijeljenoj odgovornosti. 